\title{
Misery loves company: exogenous shocks in retirement expectations and social comparison effects on subjective well-being
}

Citation for published version (APA):

Montizaan, R. M., \& Vendrik, M. C. M. (2012). Misery loves company: exogenous shocks in retirement expectations and social comparison effects on subjective well-being. Researchcentrum voor Onderwijs en Arbeidsmarkt, Faculteit der Economische Wetenschappen. ROA Research Memoranda No. 13 https://doi.org/10.26481/umaror.2012013

Document status and date:

Published: 01/01/2012

DOI:

10.26481/umaror.2012013

Document Version:

Publisher's PDF, also known as Version of record

Please check the document version of this publication:

- A submitted manuscript is the version of the article upon submission and before peer-review. There can be important differences between the submitted version and the official published version of record.

People interested in the research are advised to contact the author for the final version of the publication, or visit the DOI to the publisher's website.

- The final author version and the galley proof are versions of the publication after peer review.

- The final published version features the final layout of the paper including the volume, issue and page numbers.

Link to publication

\footnotetext{
General rights rights.

- You may freely distribute the URL identifying the publication in the public portal. please follow below link for the End User Agreement:

www.umlib.nl/taverne-license

Take down policy

If you believe that this document breaches copyright please contact us at:

repository@maastrichtuniversity.nl

providing details and we will investigate your claim.
}

Copyright and moral rights for the publications made accessible in the public portal are retained by the authors and/or other copyright owners and it is a condition of accessing publications that users recognise and abide by the legal requirements associated with these

- Users may download and print one copy of any publication from the public portal for the purpose of private study or research.

- You may not further distribute the material or use it for any profit-making activity or commercial gain

If the publication is distributed under the terms of Article $25 \mathrm{fa}$ of the Dutch Copyright Act, indicated by the "Taverne" license above, 
Maastricht University

Research Centre for Education and the Labour Market | ROA

\section{Misery loves company: \\ Exogenous shocks in retirement expectations and social comparison effects on subjective well-being}

Raymond M. Montizaan

Maarten C.M. Vendrik

\section{ROA Research Memorandum}

ROA-RM-2012/13

Research Centre for Education and the Labour Market

Maastricht University

P.O. Box 616, 6200 MD Maastricht, The Netherlands

$\mathrm{T}+31433883647 \mathrm{~F}+31433884914$

secretary-roa-sbe@maastrichtuniversity.n

www.roa.nl 


\title{
Misery loves company: Exogenous shocks in retirement expectations and social comparison effects on subjective well-being
}

\author{
Raymond M. Montizaan \\ Maarten C.M. Vendrik
}

ROA-RM-2012/13*

September 2012

Research Centre for Education and the Labour Market

Maastricht University

P.O. Box 616, 6200 MD Maastricht, The Netherlands

$\mathrm{T}+31433883647 \mathrm{~F}+31433884914$

secretary-roa-sbe@maastrichtuniversity.nl

www.roa.nl

\footnotetext{
The ROA Research Memorandum Series was created in order to make research results available for discussion, before those results are submitted for publication in journals.
} 


\section{Abstract \\ Misery loves company: Exogenous shocks in retirement expectations and social comparison effects on subjective well-being}

This study investigates the effects of social comparisons accompanying a substantial reform of the Dutch pension system on the job satisfaction of workers who are close to retirement. The reform implies that public sector workers born on January 1, 1950, or later face a substantial reduction in their pension rights, while workers born before this threshold date can still retire under the old, more generous rules. Using unique matched survey and administrative panel data on male public sector workers born in 1949 and 1950, we find strong and persistent effects on job satisfaction that are sizable compared to income effects on well-being. The drop in satisfaction is strongly affected by social comparisons with colleagues. Treated workers are less affected by the reform when the treatment group is larger in the organization where they are employed. Moreover, the social comparison effect is especially prevalent in organizations that stimulate their employees to work in teams. We also find evidence that workers compare their own replacement rate with the average replacement of comparable individuals in their organization, but the major part of the social comparison effect is non-monetary.

JEL classification: D63, D1, I3, J26

Keywords: social comparison, well-being, retirement

Raymond M. Montizaan

ROA

Maastricht University and IZA

P.O. Box 616

6200 MD Maastricht

The Netherlands

r.montizaan@maastrichtuniversity.nl
Maarten C.M. Vendrik

Department of Economics

Maastricht University and IZA

P.O. Box 616

6200 MD Maastricht

The Netherlands

m.vendrik@maastrichtuniversity.nl 


\section{Introduction}

People feel less happy when the situation in which they find themselves compares unfavorably with that of others. The relevance of such social comparisons for subjective well-being in the realm of incomes was first noticed by Easterlin $(1974,1995)$. Easterlin appealed to concepts of social comparison and adaptation to income to explain why average happiness in developed countries does not significantly rise over time as these countries become richer, whereas within a country richer people tend to be significantly happier than poorer people (the Easterlin paradox). Social comparison implies that the utility of individuals does not so much depend on the absolute level of their income but, rather, on the level of their income relative to that of others in their social reference group. A substantial theoretical and empirical literature has investigated the relevance and implications of social income comparisons for subjective well-being. Recent empirical studies generally found that there exists a systematic relative income effect on well-being (e.g., Clark and Oswald, 1996; Ferrer-iCarbonell, 2005; Luttmer, 2005; Vendrik and Woltjer, 2007; Clark et al., 2008b; Layard et al., 2009; Clark and Senik, 2010). However, with the exception of a few experimental studies that controlled the reference group (see Carter and McBride, 2009; Card et al., 2010), most empirical studies assumed reference groups that were only proxies of the actual, unobserved reference groups, leading to problems of measurement error and endogenous variation in the income of the relevant reference groups.

This study examines the extent to which social comparisons between colleagues drive the effects of a drastic change in the retirement system for the Dutch public sector on the job satisfaction of older workers. By exploiting the shock in the retirement system, we avoid the problems of potential spurious correlations and measurement error that may have biased the results in previous retirement and social comparison studies. More specifically, in 2006, the Dutch public sector was subject to a major pension reform that treated two very similar groups of employees differently. Prior to 2006, public sector workers in the Netherlands could retire at age 62 years and three months with a mean replacement rate of $70 \%$ of their average yearly earnings since 2004 . As of 2006 , those born before January 1, 1950, could continue to retire under the old rules, but for those born on or after January 1, 1950 , the mean replacement rate was lowered to $64 \%$. These younger workers now need to work an additional one year and one month to obtain the $70 \%$ replacement rate enjoyed by counterparts who may be just a few days, weeks, or months older.

We match panel survey data that contain various indicators of well-being with administrative data from the public sector's pension fund and estimate, two and three years after the shock in the pension system, the individual well-being of male workers born in 1949 and 1950 . We find strong and 
persistent effects of the drop in pension rights on the job satisfaction of treated as well as untreated workers. The impact of the shock on the job satisfaction of treated workers is equivalent to having an annual wage that is about sixty percent lower. Both the size and persistence of this impact can be fully explained as being the result of social comparisons with colleagues who are not affected by the reform as well as with those affected. We find that treated workers suffer more from the reform when they have more untreated colleagues in their organization and income group, while they suffer less when they have more treated colleagues. As can be expected, we find that the social comparison effect is more significant for those who work in sectors that stimulate team work, and less significant for workers who have alternative sources of pension income or a partner who will receive an own pension income after retirement. We also find evidence that treated workers compare their own replacement rate with the average replacement of comparable colleagues in their organization. Our results, however, strongly suggest that the major part of the social comparison effect is non-monetary. This can be attributed to feelings of being unfairly treated among those affected by the reform.

Moreover, our estimates indicate a negative external effect of the percentage of treated employees on the job satisfaction of each worker in the organization. This is the opposite of what social comparisons would imply and may hint at a negative effect of treated frustrated employees on the general atmosphere in the organization (Williamson, 1973; Zárraga and Bonache, 2005). Finally, we also find treatment, social comparison and atmosphere effects on other dimensions of life satisfaction than job satisfaction, namely on satisfaction with health, hours worked and leisure.

We contribute to the existing literature in three ways. First, our main contribution is to the social comparison literature that, in general, has difficulties to isolate exogenous variation in the income of relevant peer groups (Clark and Oswald, 1996; McBride, 2001; Clark., 2003, Bender, 2004; Ferrer-i-Carbonell, 2005; Luttmer, 2005; Vendrik and Woltjer, 2007; Clark et al., 2008b, 2010; Layard et al., 2009). Our paper is closest related to the study of Card et al. (2010) in which randomized manipulation of access to information on colleagues' wages is used to identify the effects of relative income on individual job satisfaction. They found that the information treatment asymmetrically affects workers' job satisfaction: workers with a salary below the median report a lower job satisfaction, while the satisfaction level of those with an income above the median did not change. Similarly to Card et al. (2010), we analyze social comparisons between colleagues, since, regarding the direction of comparisons, colleagues are generally the most frequently cited reference group (Clark and Senik, 2010). However, instead of using exogenous manipulation of information on differences in salaries, the main advantage of our research design is that the shock in the pension system exogenously generates variation in the average income in a reference group of workers as it affects only a specific subgroup of workers. The limited age difference between the treatment and 
control groups in our sample and the simple and transparent birth-year criterion determining entitlement to the old or new pension rights further guarantee the internal validity of our regression discontinuity design.

Second, we also contribute to the literature that has empirically analyzed the relation between retirement and well-being by shedding more light on the causal effects of an exogenous change in retirement expectations on job satisfaction, and by showing the effects of social comparison between workers with different pension rights on various domains of life satisfaction. Recent studies used panel data analysis to trace the effects of retirement transitions on well-being over time (e.g., Kim and Moen, 2002; Dave et al., 2006; Börsch-Supan and Jürges, 2006). However, these panel studies could not fully account for spurious correlations and reverse causality between retirement and well-being over time (e.g., due to negative health shocks). An exception is the study of Charles (2004), who controlled for this by instrumenting retirement on the basis of discontinuous age-specific retirement incentives in the US social security system and changes in laws affecting mandatory retirement and social security benefits. The author found compelling evidence that retirement has a positive causal effect on mental well-being after ascertaining that retirement and well-being are simultaneously determined while failing to control for reverse causality would lead to the false conclusion that retirement has a negative effect on well-being. Our findings of strong effects of changing retirement expectations on well-being are consistent with the Charles finding. ${ }^{2}$

Third, our study does not focus on the actual transition into retirement, as most retirement studies have, but it shows that having to adjust expectations about retirement due to an exogenous shock in the pension system has strongly negative effects on workers' individual well-being. ${ }^{3}$ The shock substantially compromises job satisfaction, with the potential result of decreasing effort provision and individual productivity among treated workers. ${ }^{4}$ Our results are consistent with those of Falba et al. (2008), who examined the impact on mental well-being of deviations of actual retirement dates from preceding expectations and found that mental well-being is negatively affected for those working longer than expected, as well as for those working less long than expected (see Nuttmann-

\footnotetext{
${ }^{2}$ Our study is also related to studies on the effects of other bad life shocks. Among others, Clark and Oswald (1994), Winkelmann and Winkelmann (1998), and Clark et al. (2008a) have shown that unemployment and layoffs significantly reduce well-being, with significant lag and lead effects. Other studies have focused on the relation between disability shocks and well-being (Oswald and Powdthavee, 2008), environmental shocks (Luechinger, 2009), divorce effects (Lucas, 2005; Gardner and Oswald, 2006), and the effects of winning the lottery (Gardner and Oswald, 2007).

${ }^{3}$ This is also shown in De Grip et al. (2012) for the case of depression. However, that study does not focus on social comparison effects. Our study is also related to the literature on external effects in organizations since our estimates indicate a negative external effect of the percentage of treated employees on the job satisfaction of each worker in the organization.

${ }^{4}$ See Montizaan et al. (2012) for the important role of reciprocity in this.
} 
Schwartz (2004), Bossé et al. (1987), and Dreyer (1989) for related studies). However, unlike Falba et al. (2008), who analyzed the effects of deviations from retirement expectations on a one-sided measure of well-being (depression) ${ }^{5}$, this study uses answers to self-assessed questions on job satisfaction and other dimensions of life satisfaction, and documents strong and persistent social comparison and external effects on individual well-being. Since the impact of policies on the wellbeing or welfare of citizens is an essential concern of economic policy per se and job satisfaction is an important determinant of workplace performance and individual productivity (Jones et al., 2008), these social comparison effects should be taken into account when modeling the effects of a drop in the generosity of pensions on productive labor supply. ${ }^{6}$

This study proceeds as follows: Section 2 presents a brief description of the institutional setting of the pension system in the Netherlands and the policy change that was implemented in January 2006. Section 3 describes the data and examines the validity of our natural experiment. The econometric model that we use is explained in Section 4. Section 5 presents the main estimation results and Section 6 gives a robustness analysis for heterogeneous subsamples. We close with a discussion of our conclusions.

\section{The shock in the Dutch pension system}

The Dutch pension system consists of three pillars: The two main pillars consist of a flat-rate public scheme to which all residents are entitled at the age of 65 and earnings-related sectoral pensions of the defined-benefit type that enable most employees in the Netherlands to retire early, before the age of 65. The third pillar includes all voluntarily built-up savings supplementary to the occupational pensions and public scheme, typically taken as annuities through an insurance company. However, due to the well-established sectoral pensions in the second pillar, the third pillar is less well developed in the Netherlands.

\footnotetext{
${ }^{5}$ Similarly, Charles (2004) and De Grip et al. (2012) used the one-sided measures of depression and loneliness.

${ }^{6}$ In the past two decades, policy makers in most industrialized countries have developed new incentives to increase the labor force participation of older workers to counter the negative effects of demographic change on the labor supply and sustainability of extant retirement systems. The literature on retirement has shown that reducing the generosity of pensions or increasing the eligibility age for retirement may be an effective policy measure to delay retirement and to reduce the fall in the future labor supply (Kapteyn, 1998; Börsch-Supan, 2000; Gruber and Wise, 2004; Coile and Gruber, 2007; Coile and Levine, 2007). However, most studies on retirement build implicitly on the assumption that the individual well-being and effort provision of workers who face a cut in the generosity of their pension are not affected by the shock in the pension system.
} 
For individual employees, participation in the sectoral pension schemes is generally mandatory, which ensures that more than $95 \%$ percent of the employed population is covered and therefore eligible for early-retirement pensions. These pension schemes are predominantly fully funded and are negotiated between unions and employer organizations at the sector or firm level and are officially set forth in collective agreements. In accordance with the Pensions and Savings Act (Pensioen en Spaarfondsenwet), the administration of the occupational pension schemes is delegated to pension funds to which both employers and employees contribute. The Algemeen Burgelijk Pensioenfonds (ABP) is the pension fund for public sector workers in the Netherlands. Until 2006, sectoral pension schemes were facilitated by the government through preferential tax treatment that allowed employees and employers to deduct their contributions to the sectoral early-retirement schemes from their pre-tax income. This tax exemption granted large tax advantages due to the progressive tax system (Euwals et al., 2006).

A reform of the Dutch pension system conducted in 2006 provides the basis for our natural experiment. To stimulate the labor force participation of older workers, the government abolished the favorable tax treatment of early sectoral retirement schemes in the second pillar for all workers born after $1949 .^{7}$ In the summer of 2005 , anticipation of the change in tax rules led to a new collective bargaining process on the introduction of a new pension scheme for the public sector (the ABP flexible pension scheme). Given the high number of older workers in the public sector, it had by then been acknowledged that reforms of the pension system would be a necessity. Therefore, a change in pension rights was not entirely unexpected. However, the timing of the reform as well as the particular implementation of a discontinuous assignment rule that contained a strongly differential treatment of workers born around January 1, 1950, came as a surprise when it was announced on July 5, 2005. Following the announcement, ABP launched a campaign in the second half of 2005 to explain the implications of the new system which made sure that all 1.2 million ABP participants should have been familiar with the implications of the changes in the pension system before the new pension scheme came into effect.

The new pension scheme for public sector workers was launched on January 1, 2006. Workers born before 1950 remain entitled to the old, more generous pre-pension rights if they have worked continuously in the public sector since April 1, 1997. This means that such workers can still retire early, between ages 55 and 65 . Retirement at age 62 years and three months yields a pension benefit for those born before 1950 at a replacement rate of $70 \%$ of average yearly earnings since

\footnotetext{
${ }^{7}$ The abolition of favorable tax treatment also applies to workers in the private sector.
} 
$2004 .{ }^{8}$ However, employees born after 1949 or before 1950 but who did not work continuously in the public sector since 1997 are subject to the new and less generous system. This new system entails (i) a drop in pension benefits, (ii) an increase in pension contribution payments to partly account for the drop in pension wealth resulting from (i), and (iii) stronger incentives to continue working, generated by penalties on pension income when retiring before commencement of the state pension at age 65 and by supplements for later retirement. Moreover, the eligibility age for pension benefits is increased to 60 years and workers can decide to continue working until their 70th birthday. Note that the supplements to the pension benefits for later retirement ensure that workers who already before the shock in the pension system planned to continue working until they are 65 do not experience a drop in pension wealth. ${ }^{9}$ However, together with the penalties on pension income before the retirement age of 65 , the increase in the eligibility age implies that workers' options to retire early were always reduced.

For younger workers, the increase in pension contributions partly compensates for the decrease in pension benefits over time. However, public sector workers born just after 1949 do not have enough time to fully compensate for this drop in pension benefits. Therefore, as a consequence of both the abolition of the tax rules and the steeper early retirement scheme, workers born shortly after December 31, 1949, are confronted with a substantial decrease in pension benefits if they wish to retire at age 62 and three months. More specifically, the average replacement rate at that age has dropped to $64 \%$ and they must work an additional 13 months to qualify for a pension at a replacement rate of $70 \%{ }^{10}$

Public sector workers can react in three possible ways to the shock in the pension system: (i) They can postpone retirement to reduce the gap in their pension wealth when retiring early; (ii) they can decide to retire at the initially planned date against a lower replacement rate, in which case they have to accept that their lifetime pension income is lower due to the lower replacement rate; or (iii) they can increase their individual private (pension) savings. A relevant saving mechanism is the Life-Course Savings program (Levensloopregeling), which was introduced by the Dutch government in 2006 . This program allows tax-free savings of up to $12 \%$ of annual earnings in a fund

\footnotetext{
${ }^{8}$ Until January 1, 2004, pension benefits were calculated using wage earnings in the year prior to retirement. Since 2004 , pension benefits have been calculated using average annual earnings since 2004.

${ }^{9}$ The proportion of workers who planned to retire at the age of 65 before the shock in the pension system is extremely small. Approximately $80 \%$ of all workers in the Netherlands who retired under the old pre-pension rules in 2004 chose early retirement at the age of 62 years or younger (Statistics Netherlands, 2009).

${ }^{10}$ Nevertheless, a small minority of older employees born after 1950 can still retire early without experiencing a substantial drop in income, namely, employees with burdensome jobs (firemen, ambulance, and police personnel), who are eligible for special arrangements that allow early retirement against a replacement rate of at least $70 \%$ between ages 55 and 61 . However, these workers are not included in our data.
} 
that can be used to finance periods of non-employment, such as a sabbatical or early retirement. Workers are allowed to save up to $210 \%$ of their annual earnings in this Life-Course Savings fund, which can be used to finance about two years of early retirement. Special arrangements were made for older workers who were most affected by the pension reform. Those who were born in the years 1950 through 1954 are allowed to save more than $12 \%$ of their annual earnings, so long as the cumulative maximum does not exceed $210 \%$ of annual earnings. However, it must be noted that workers of the 1950 cohort must save approximately $14 \%$ of their annual earnings for seven years to finance early retirement at age 62 . It is likely that only a very small fraction of such workers are willing or capable of saving such a high proportion of their earnings each year before retirement.

\section{Data and descriptives}

\subsection{Data collection}

We use unique panel survey data that are matched to administrative data for male full-time public sector workers born in 1949 or $1950 .{ }^{11}$ The administrative data come from the Dutch pension fund for public sector employees (ABP). The data contain detailed information on the number of years worked and contributed to the public sector's pension fund, annual wages, tenure in the public sector, number of working hours, and employer organization.

The survey data are available for three years. The data in the initial wave were collected in two stages one year after the introduction of the new pension system. In the first stage, all 27,871 male public sector employees born in 1949 or 1950 were sent a request to participate in the study and to give their e-mail address. In the second stage, in March 2007, the 11,458 employees who gave their permission were sent an e-mail with a link to the survey. ${ }^{12}$ To avoid biases such as mis-measurement due to possibly highly inflated answers when surveys do not ask the respondents to answer the questions truthfully (see Harrison and List, 2004, for a discussion on this topic) or affected answers since the respondents were aware of the survey's experimental objectives, the invitation letter and the e-mail with the link to the survey bore great similarities to the cover letter advocated by Dillman

\footnotetext{
${ }^{11}$ We focus on male employees, since in the Netherlands male employees aged 56 or 57 years are usually the main wage earners, while female workers in the same birth cohort predominantly have disrupted careers. In this age range, on average, men have contributed for 28 years to the pension fund, whereas women have contributed on average for only 16 years. Moreover, only a small, select group of these women is still working. In the public sector, only $30 \%$ of all employees born between 1940 and 1950 are women, and 72\% of these work in a flexible or part-time job (Statistics Netherlands, 2009).

${ }^{12}$ The likelihood of selectivity bias due to the use of the Internet is negligible, because $91 \%$ of public sector employees aged 55 years or older have an Internet connection at home (TNS Nipo, 2006). Moreover, the respondents were also able to fill in the questionnaire at work.
} 
(1978). The letter and the e-mail conveyed general information about the social usefulness of the study without revealing the survey's experimental character. They also explicitly ensured confidentiality such that the respondents need not fear repercussions from responding in a socially undesired manner. Furthermore, references to the natural experimental character of the research project were avoided in the survey itself and explicit questions that could give away the survey's experimental character were not included.

In total, 8,516 individuals started answering the questionnaire, 7,739 of whom successfully completed it. Analyses of the administrative data confirmed that these 7,739 respondents formed a representative sample of all male public sector employees who were born in 1949 or 1950. Moreover, the response rate to the survey for the two birth cohorts was virtually identical and a probit analysis showed that selection into the survey in 2007 was not related to the treatment. The probit analysis included control variables available in the administrative data, such as the work sector, contractual work hours, number of years contributed to the pension fund, birth month, and yearly wage (in logs), and resulted in a small and insignificant coefficient for the treatment dummy (marginal effect is -0.007 with a standard error of 0.020$)$.

This study relies on data from the second and third waves of the survey, held in March 2008 and 2009. We use only the second and third waves since only they contain information on subjective well-being. The second wave includes 6,070 respondents who successfully completed the questionnaire. The number of respondents to the third wave (7,711 respondents) is higher due to an update of the list of e-mail addresses. ${ }^{13}$ The analysis is further restricted to full-time workers who have worked continuously in the public sector since 2007. For these workers, the pension reform is clear since age is the only criterion that determines whether a worker belongs to the treatment group or the control group. Remember that those who did not work continuously are also subject to the new pension rules. Hence, in principle, we have a second treatment group next to those who were born in 1950. However, our analyses do not use this group since it is very likely that unobserved characteristics that may have caused the career break since 1997 are also correlated with our

\footnotetext{
${ }^{13}$ Panel attrition was predominantly due to changes in e-mail addresses. Therefore, in 2009, a new call to participate in the study was sent by mail to individuals whose e-mail addresses no longer existed. Moreover, all individuals who did not react to the first call received a second request in 2009 to participate in the study and to give their e-mail address. Probit analyses to measure selection into the survey for the years 2008 and 2009 show that the marginal effect of the treatment dummy remains small and insignificant.
} 
indicators of subjective well-being. ${ }^{14}$ The final sample consists of 5,195 men in 2008 and 6,612 men in 2009.

Our empirical analysis is based on subjective, self-reported measures of well-being that were extracted from individual answers to the survey's satisfaction questions. ${ }^{15}$ Psychologists and economists have made ample use of such questions in the past three decades. In particular, for measuring job satisfaction, we make use of the following question that was asked in the surveys of 2008 and 2009:

Please answer by using the following scale, where 0 means totally unsatisfied and 10 means totally satisfied.

1) How satisfied are you with your job?

Furthermore, we asked questions on life satisfaction and its underlying domains, which gives us the advantage of observing how the shock in the pension system affects different aspects of life satisfaction:

We would like to ask you about your satisfaction with your life. Please answer by using the following scale, where 0 means totally unsatisfied and 10 means totally satisfied.

1) How satisfied are you at present with your life as a whole?

2) How satisfied are you with your wage?

3) How satisfied are you with the number of hours you work per week?

4) How satisfied are you with the amount of spare time you have?

5) How satisfied are you with your household income?

6) How satisfied are you with your pension wealth?

7) How satisfied are you with your health?

Answers to the first three questions are available in both waves. Answers to the other four questions are only available in the 2009 wave.

Previous studies have shown that the reliability of these subjective well-being measures is sufficiently high to support much of the research that is currently undertaken on subjective well-being, particularly in studies where group means are compared, that is, across activities or demographic groups. Yet, the reliability of these measures is lower than that typically found for education, income,

\footnotetext{
${ }^{14}$ This resulted in the exclusion of 260 observations from the 2008 wave of employees born in 1949 who were not eligible for the old pension rights. In 2009, 239 employees were excluded. These groups are not large enough to serve as an additional control group.

${ }^{15}$ To avoid framing effects, we made sure that the well-being questions were not placed directly after questions on pension rights, but were placed after a block of questions on education and training courses.
} 
and many other microeconomic variables, due to their discreteness and non-random measurement errors (Frey and Stutzer, 2002a,b; Ferrer-i-Carbonell and Frijters, 2004; Luttmer, 2005; Krueger and Schkade, 2008).

In addition to the questions on well-being, we gathered detailed information on retirement expectations to assess whether public sector employees are indeed aware of the shock in their pension rights and whether their retirement expectations in general are reliable. Questions were asked on when respondents expected to retire and how high their pension benefits would be as a percentage of their net wage income if they retired at the age of 62,63, or 65. Lastly, we asked questions in the 2009 wave on the partners of the male public sector employees in our sample.

\subsection{Descriptives}

Table 1 presents descriptive statistics of the 2008 and 2009 waves for the entire sample, the treatment group, and the control group. Columns 5 and 10 of Table 1 give the results of a simple t-test for the equality of the means of a variable for those born in 1949 or 1950. The table shows that, on average, workers in the public sector are reasonably satisfied with their job. The mean score on the job satisfaction question in 2008 was 6.7 with a standard deviation of 1.8. In 2009, the score was somewhat higher (7.0 with a standard deviation of 1.7). Workers are also rather satisfied with their life as a whole ( 7.7 with a standard deviation of 1.3 in 2008). Concerning the specific dimensions of life satisfaction, it is striking that all scores on these aspects are lower than the score on the life satisfaction question. Furthermore, we observe that workers are, in general, less satisfied with their wage and hours worked but are more satisfied with their household income and health.

Table 1 shows differences in the scores on the job satisfaction measure between the group of workers who can still retire under the old rules and those with reduced pension rights. In 2008 and 2009 the score of the job satisfaction variable is, on average, 0.10 lower for those born in 1950 . The ttests show that the difference between the two groups is statistically significant for 2009. At first sight the differences may seem small, but when we compare the size of the treatment effect in Section 5.1 with the effects of income changes on job satisfaction, it will turn out that the effect is sizable. Furthermore, Figure 1 also shows a clear discontinuity in the job satisfaction of those born in 1949 as compared to 1950 . Hence, these exploratory analyses already provide some preliminary evidence of a treatment effect.

When we look at our measures for life satisfaction and the other dimensions of life satisfaction, we observe from Table 1 that almost all scores are lower for those born in 1950. More specifically, the t-tests, based on this rough comparison, show that there are significant differences 
between the control and treatment groups in life satisfaction and in satisfaction with hours worked and leisure time.

These differences in average satisfaction between the treatment and control groups are the result of differences in the underlying distributions of the individual satisfaction scores toward lower scores for the 1950 group. In particular, in the 2009 sample, the percentage of poor job satisfaction scores below 6 is 14.4 for birth year 1950 versus 13.2 for birth year 1949, a factor of 1.1 higher for 1950, while the percentage of high job satisfaction scores above 7 is 72.4 for 1950 versus 74.3 for 1949. For the 2008 sample, the differences in percentages are similar but somewhat smaller. Thus, among those born in 1950, there are more men dissatisfied and fewer satisfied with their job than among those born in $1949 .^{16}$

Next, we verify whether the employees in our sample are aware of the exogenous shock in their pension rights and that the observed difference in the well-being indicators is not due to some artifact in the data. The answers to the questions on retirement expectations can help us to deal with this matter. The summary statistics in Table 1 show that respondents who are affected by the pension reform indeed expect a significantly lower replacement rate if they retire at the age of 62 . The mean difference in the expected retirement benefits between the treatment and control groups is 5.1 percentage points, which is remarkably close to the actual mean difference between these groups. ${ }^{17}$ Moreover, Table 1 shows that both groups expect a higher replacement rate if they retire later and that the difference in the expected replacement rates at the age of 65 between both groups is extremely small. This finding is consistent with the new pension system due to its specific penalty structure, which enables workers born in 1950 to retire at the age of 65 without a drop in their pension wealth. Given the fact that, on average, workers can assess their replacement rate at the age of 62 rather well and that their answers show some knowledge of the penalties and supplements provided by the new pension system, it is reasonable to conclude that employees are, on average, aware of the consequences of the new pension system. ${ }^{18}$ Furthermore, Table 1 shows that the decrease in pension

\footnotetext{
16 In the 2009 sample, the percentage of poor life satisfaction scores below 6 is 4.0 for birth year 1950 versus 3.3 for birth year 1949, a factor of 1.4 higher for 1950, while the percentage of high life satisfaction scores above 7 is 68.8 for 1950 versus 71.8 for 1949. For the 2008 sample, the differences in percentages are again similar but somewhat smaller. Thus, among those born in 1950, there are more unhappy and fewer very happy men than among those born in 1949.

${ }^{17}$ Note also that the expected replacement rates for both groups dropped considerably in 2009 . This can be explained by the financial crisis causing a dramatic fall in the reserves of the public sector pension fund. The fall in reserves induced the pension fund to (temporarily) stop applying indexation, that is, adjusting pensions to the inflation rate or the wage trend.

${ }^{18}$ Figure 2 shows the expected replacement rates at the age of 62 for workers born in 1949 and 1950. The figure shows that there is a clear break in expectations around the threshold date (December 31, 1949).
} 
rights due to the pension system reform has increased the expected retirement age. Employees born in 1949 expect, on average, to retire three months later than those born in 1950.

Finally, we check whether individuals in the treatment and control groups have, apart from the differences in their pension rights, similar characteristics. Table 1 shows that most differences between the group of workers born in 1949 and those born in 1950 are indeed sufficiently small to ensure the validity of the natural experiment. Job characteristics and personal characteristics are similar across both groups and, with a few exceptions, not significantly different from each other. ${ }^{19}$ The differences in the yearly wages and number of years contributed to the pension fund are due to the small age difference between the control and treatment groups. The difference in life-course savings investments is a logical consequence of the pension reform; that is, those with reduced pension rights increase their private savings to (partly) compensate for their lost pension wealth. The fraction of married individuals is slightly higher among the group that is not affected by the reform. ${ }^{20}$ It will therefore be important to control for marital status in our analyses.

\section{Econometric model}

People tend to compare themselves with others. This is a deeply ingrained human inclination that is likely to play an important role in the present context as well (see Frey and Stutzer (2002b) for a literature review). The frustration of those born in 1950 about the tax reform may stem not so much from disappointment about the fall in their expected replacement rate at age 62 per se but, rather, from the fact that they are hit by the reform while people slightly older and born in 1949 are not. In particular, those born in 1950 may compare their situation with that of people of similar age, sex, and socioeconomic characteristics in their social environment.

We expect men born in 1950 to be sensitive to the extent to which colleagues in their organization also suffer from the reform. Since employees are likely to compare themselves primarily with colleagues in similar positions, and hence similar levels of income, we assume that their social reference groups consist of male colleagues with incomes that are within $+16,5$ and $-16,5$ percentage points from their own income level in the income distribution of their organization (so within the

\footnotetext{
${ }^{19}$ Table 1 shows that most workers in our sample are highly educated, which can be explained by the fact that these workers are overrepresented in the public sector. The fraction of highly educated workers in our sample is consistent with the OSA Labor Supply Panel, which is a representative panel survey of the working population in the Netherlands.

${ }^{20}$ This is due to a cohort effect according to which younger cohorts tend to be married less often.
} 
same moving income 'tertile'). ${ }^{21}$ Because of this reason, and due to the fact that administrative data on the numbers of employees in the public sector organizations are only available for those who were born in 1949 and 1950, we further have to assume that the social reference group of each male employee in our sample consists of all male colleagues born in 1949 and 1950 who belong to the same moving income tertile. In agreement with the standard approach in the empirical social comparison literature, we model the social comparison effect of this reference group on the job satisfaction of the employee as the effect of the average treatment in the reference group. The average treatment for each employee is determined as the number of barely treated male colleagues (those born in 1950) that are within the income tertile of the respective employee as a fraction of all barely treated and barely untreated colleagues (those born in 1949 and 1950) that belong to same income tertile. $^{22}$

In our main analyses, we make use of a regression discontinuity design to identify the causal effects of the shocks in pension rights on job satisfaction (Van der Klaauw, 2002). More specifically, for the measurement of the effects of the individual treatment as well as the average treatment in the social reference group, we estimate a regression discontinuity model with random effects of the form

$$
J S_{i t}=\alpha+\beta_{1} T_{i}+\beta_{2} \bar{T}_{i t}+\beta_{3} T_{i} \bar{T}_{i t}+\gamma_{1} B_{i}+\gamma_{2} B_{i} T_{i}+\gamma_{3} B_{i} \bar{T}_{i t}+\gamma_{4} B_{i} T_{i} \bar{T}_{i t}+\boldsymbol{\delta}^{\prime} \mathbf{X}_{i t}+u_{i}+e_{i t}
$$

Here $J S_{i t}$ stands for the job satisfaction of employee $i$ in year $t, T_{i}$ represents the treatment dummy, which is zero if employee $i$ was born in 1949, and one if this employee was born in 1950, $\bar{T}_{i t}$ denotes the average treatment in the social reference group (measured as the number of treated employees as a fraction of all treated and untreated employees), $B_{i}$ stands for the running variable birth date (expressed in days, normalized to 0 at December 31 of 1949, and divided by the number 365 of days in a year), $\mathbf{X}_{i t}$ is a vector of control variables, $u_{i}$ denotes random effects, and $e_{i t}$ is the error term. This approach corresponds to a sharp regression discontinuity design (Van der Klaauw, 2002). Our identifying assumption is that there are no other policies or circumstances that affect the 1949 and

\footnotetext{
${ }^{21}$ They may also compare themselves with female colleagues of the same age, but women are excluded from our sample because many of them tend to have interrupted working careers, and hence much lower replacement rates than their male colleagues. This makes these women less comparable with their male colleagues in terms of pension rights.

${ }^{22}$ Table 2 gives information on the average number of treated and untreated workers by organization and income tertile. Treated and untreated workers born in 1950 and 1949, respectively, can compare themselves with on average 64 employees born in 1950 and 1949 in their organization who are in the same income tertile. The mean of the fraction barely treated is 0.52. It is relevant to stress that organizations in the public sector (2,342 organizations in total) are relatively large compared to those in the private sector. Organizations have on average 5,436 employees (median size is 1,146). In the following, we will often, for the sake of brevity, drop the adverb "barely" when referring to barely treated and barely untreated workers.
} 
1950 cohorts differently in a discrete way. This is a highly plausible assumption because there is no indication of the existence of such other policies or circumstances.

The term $\beta_{1} T_{i}$ indicates the main effect of the treatment, which is expected to be negative $\left(\beta_{1}<0\right)$. The terms $\beta_{2} \bar{T}_{i t}$ and $\beta_{3} T_{i} \bar{T}_{i t}$ model the social comparison effects of the average treatment in the social reference group. Taking the two terms together as $\left(\beta_{2}+\beta_{3} T_{i}\right) \bar{T}_{i t}$ shows that parameter $\beta_{2}$ represents the social comparison effect on the job satisfaction of the untreated workers whereas $\beta_{2}+\beta_{3}$ denotes the social comparison effect on the job satisfaction of the treated workers. In line with Card et al. (2010), who found no significant social comparison effect on the job satisfaction of above-median earners, we expect the social comparison effect on the untreated employees to be insignificantly different from zero $\left(\beta_{2}=0\right)$. In that case, the social comparison effect on the treated employees is given by $\beta_{3}$, which we expect to be positive $\left(\beta_{3}>0\right)$, because we anticipate that treated workers will feel less frustrated when several colleagues in the same income group suffer from the treatment as well (shared misery). ${ }^{23}$

The next four terms including the running birth date variable $B_{i}$ control for confounding effects of potential age trends or shifts in age trends due to the shock in the pension system on the main and interaction effect of the treatment (as required in a sharp regression discontinuity design). It is well-known that well-being is a function of age. Several cross-sectional studies have found that well-being may increase with age (Campbell et al., 1976; Prenda and Lachman, 2001), while other studies have found that this relationship is U-shaped (Blanchflower and Oswald, 2008). This empirical evidence suggests that it is relevant to control for these potential age trends and to investigate whether potential differences in job satisfaction or in social comparison effects on job satisfaction between the two birth cohorts go beyond what would be expected based on the treatment effect alone. Finally, we include a set of control variables $\mathbf{X}_{i t}$ to account for differences between the treatment and control groups further away from the threshold of January 1, 1950. This set includes yearly wage (in logs), marital status, years contributed to the pension fund, contractual working hours, number of doctor visits, year of measurement, educational level, and sub-sector fixed effects.

The choice for using a random effects model is motivated by the need to account for unobserved heterogeneity. ${ }^{24} \mathrm{We}$ can safely assume that the coefficient of the treatment dummy is not

\footnotetext{
${ }^{23}$ The implied asymmetry in social comparison between treated and untreated workers is analogous to the asymmetry in income comparisons that was already postulated by Duesenberry (1949), and that has empirically been confirmed by Ferreri-Carbonell (2005), Vendrik and Woltjer (2007), and Card et al. (2010). Vendrik and Woltjer interpret the asymmetry as a kind of loss aversion in the context of prospect theory, while Card et al. relate it to the inequity-aversion model of Fehr and Schmidt (1999).

${ }^{24}$ The random effects model implies the strong assumption that the error terms are random and not correlated with the observable variables. To address this issue, various studies have included so-called Mundlak terms. The benefit of Mundlak terms is that the time-invariant correlation between the unobservables and the observables acts only through the time
} 
biased by unobserved individual heterogeneity, such as differences in individual scales of job satisfaction, because of this study's experimental setup. After all, assignment to the treatment or control group is exogenous and as good as random just near the threshold, rendering the coefficient of the treatment dummy unbiased. However, this does not hold for relevant control variables such as the yearly wage, marital status and the number of years contributed to the pension fund. Although we are primarily interested in the coefficient of the treatment variable, it is relevant for our understanding of the treatment effect to compare its size more closely to unbiased correlations for these other variables. Furthermore, the random effects model treats job satisfaction as a cardinal construct. There are two reasons why we use this type of model: (i) Panel estimation uses the whole sample rather than a reduced sample in models that deal explicitly with the ordinal character of the dependent variable. (ii) The results of cardinal models are more intuitive and easier to interpret. In addition, cardinal and ordinal analyses of life satisfaction yield, in general, similar results (Ferrer-i-Carbonell and Frijters, 2004). However, consistent with the existing literature, we find that the estimates of ordered probit models including random effects do not differ much from those in our main analyses (see Table A.1 in Appendix A.1). ${ }^{25}$

\section{Main results}

\subsection{Social comparison effects}

Table 3 shows the results of regression discontinuity model (1) for the effects of the pension reform on job satisfaction. Column 1 of Table 3 contains the results of a baseline specification, where, apart from the indicator for the reform and the controls for the running birth date variable and year of measurement, no other variables are included. Column 2 of Table 2 includes the other control variables and Column 3 adds the effects of the average treatment in the social reference group and the corresponding control variables for birth date effects.

The results of the specifications presented in Columns 1 and 2 of Table 3 show that the reform has a significantly negative effect on job satisfaction and that the magnitude of this effect hardly changes when we add controls for individual heterogeneity. The reform reduces job satisfaction by approximately -0.22 point on the $0-10$ scale of job satisfaction. The treatment effect on job

averages of the observable variables, while the remaining part of the unobserved effect is supposed to be independent of the observables (Mundlak, 1978). We also estimated models including these Mundlak terms (see Table A.1 of Appendix A.1). However, since the coefficient of the wage rate is insignificant in these specifications due to lack of variation over time and since we want to compare the size of the treatment effect to the coefficient of the wage rate and since this size is not significantly affected by the inclusion of the Mundlak terms, we proceed by showing the results from standard random effect models.

${ }^{25}$ Table A.1 also shows that we find similar results using OLS. 
satisfaction in Column 3 is much larger than those in Columns 1 and 2 because of the presence of an interaction term of the treatment dummy with the average treatment in the social reference group in Column 3. In line with our expectations, the coefficient of this interaction term is positive and strongly significant. ${ }^{26}$ This indicates that there is indeed a social comparison effect on treated employees: They do not feel as bad in their job when more of their colleagues within the same income tertile suffer from the treatment as well. ${ }^{27}$ This is a rather strong effect as an increase of one standard deviation $(0.225)$ in the fraction of treated employees raises job satisfaction by $0.769 * 0.225=0.17$.

Contrary to our expectations, the main effect of the average treatment in the reference group is significant and negative. This suggests that there is a negative external effect of the percentage of treated employees on the job satisfaction of each older worker in the organization, which is the opposite of what social comparison would imply. It could be that frustrated employees born in 1950 have a negative effect on the general atmosphere in the organization (Williamson, 1973; Záragga and Bonache, 2005). ${ }^{28}$ However, for treated workers this negative atmosphere effect is more than compensated by the positive social comparison effect of the fraction of treated colleagues $(-0.584+$ $0.769=0.185$ ). Thus, the total net effect of the treatment on the job satisfaction of the treated workers is on average $-0.583+0.185 * 0.522=-0.486 .{ }^{29}$ The untreated workers only experience a negative atmosphere effect on their job satisfaction with an average magnitude of $-0.584 * 0.522=-0.305$. This amounts to more than $60 \%$ of the total average negative treatment effect of -0.486 on the job satisfaction of treated workers. Thus, rather than being relieved by their escape from the pension

\footnotetext{
${ }^{26}$ Table A.2 in Appendix A.1 shows that our results are robust to the use of alternative income brackets for calculating the social reference group.

${ }^{27}$ Interestingly, this is analogous to the mitigating effects of higher reference group unemployment (at the regional, partner, or household level) on the loss of well-being of British and German unemployed people (Clark, 2003; Clark et al., 2010). Note that this effect cannot be distinguished from the complementary possibility that treated employees do not feel as bad when fewer colleagues within the same income tertile are untreated.

${ }^{28}$ We also performed control analysis in which we controlled for the size and a proxy for the age structure of the organization. Table A.3 of Appendix A.1 shows that our results are robust to the inclusion of these organization characteristics. This implies that the atmosphere effect is unlikely to pick up a potential negative effect of a higher percentage of relatively younger workers in the organization on the job satisfaction of older workers. The atmosphere effect is comparable to the negative effect of regional unemployment on the life satisfaction of employed and unemployed men with good job prospects, as found by Clark et al. (2010). It might also reflect feelings of empathy or inequality aversion of untreated colleagues towards their less lucky treated colleagues.

${ }^{29}$ The mean of the fraction treated by organization and income tertile is 0.522 .
} 
reform, those born in 1949 are confronted with a negative atmosphere effect due to the retrenched pension rights of their colleagues. ${ }^{30}$

A remarkable implication of these results is that the pension reform not only has a strong negative effect on the job satisfaction of the treated workers, but also indirectly via a less congenial atmosphere has a sizable negative effect on the job satisfaction of the untreated workers. To obtain a better idea of the sizes of both impacts, it is instructive to compare them with the coefficient of the log wage. Although the latter should only be interpreted as a correlation since there may be spurious correlations and reverse causality between wage and job satisfaction, resulting in potential, probably upward, biases in the coefficient of the log wage, the comparison nevertheless suggests that the impacts of the reform are sizable. If we assume that causality runs from log wage to job satisfaction, the impact of the reform on the treated workers is equivalent to having an annual wage that is about $60 \%$ lower while the impact of the reform on the untreated workers corresponds to a fall in the wage by more than $40 \%{ }^{31}$

\subsection{Absolute and relative treatment effects and adaptation}

From the previous results, it is striking that the social comparison effect on the job satisfaction of treated workers is larger in size than the main treatment effect. In the following this will be shown to imply that the latter treatment effect can be fully explained as being the result of social comparison with colleagues. To see this we rewrite equation (1) in Section 4 as

$J S_{i t}=\alpha+\widetilde{\beta}_{1} T_{i}+\beta_{2} \bar{T}_{i t}+\widetilde{\beta}_{3} T_{i}\left(T_{i}-\bar{T}_{i t}\right)+\gamma_{1} B_{i}+\gamma_{2} B_{i} T_{i}+\gamma_{3} B_{i} \bar{T}_{i t}+\gamma_{4} B_{i} T_{i} \bar{T}_{i t}+\boldsymbol{\delta}^{\prime} \mathbf{X}_{i t}+u_{i}+e_{i t}$

\footnotetext{
${ }^{30} \mathrm{We}$ also performed placebo analyses in which we estimated Equation 1 for life satisfaction and its underlying domain satisfactions other than job satisfaction (Table A.4 in Appendix A.1.) These analyses buttress our findings by showing that the social comparison effects are significant and large for satisfaction with the number of hours worked and the amount of leisure time. As the pension reform implies that many workers have to work longer, it is highly conceivable that especially these leisure-related domains of satisfaction are affected. Moreover, the significant social comparison effect on health satisfaction is in line with the results of De Grip (2012), who found that mental health of treated workers declined. Finally, we find no significant social comparison effect for domains of life satisfaction that should not directly be affected by the pension reform (satisfaction with present household income and wage).

${ }^{31}$ For the treated workers the equivalent decrease in $\Delta \ln w$ equals $-0.486 / 0.548=-0.887$, implying a fall in $w$ by a factor $\exp (-0.887)=0.412$, and hence a fall by $(1-0.412) \times 100=58.8 \%$. For the untreated workers the equivalent decrease in $\Delta \ln w$ is $-0.305 / 0.548=-0.557$, implying a fall by $42.7 \%$. Put somewhat differently, as a decrease of one standard deviation in the $\log$ wage is 0.325 , the impact of the reform on the job satisfaction of the treated workers is equivalent to that of a decrease of $0.887 / 0.325=2.7$ standard deviation in the log wage. As the wage coefficient may be upwardly biased, these estimates of the sizes of the impacts of the pension reform in terms of falls in the wage seem to represent lower bounds, and hence suggest that the effects are large.
} 
where $\widetilde{\beta}_{1}=\beta_{1}+\beta_{3}$ and $\widetilde{\beta}_{3}=-\beta_{3}$. The term $\widetilde{\beta}_{3} T_{i}\left(T_{i}-\bar{T}_{i t}\right)$ denotes the job satisfaction effect of the treatment relative to the average treatment in the social reference group of the treated employee. Accordingly, the term $\widetilde{\beta}_{1} T_{i}$ represents the absolute component of the treatment effect at given relative component of the treatment effect. Column 2 of Table 4 shows that this absolute treatment effect $(0.186)$ is insignificant while the relative treatment effect $(-0.769)$ is statistically significant at the 5\%level. The overall main treatment effect on job satisfaction as presented in Column 1 of Table $4^{32}$ (0.583 ) is thus revealed to have only a significant relative component, and hence seems to be entirely caused by social comparison with colleagues. In addition, there is a negative atmosphere effect of the average treatment in the organization on treated and untreated employees alike.

An interesting general feature of happiness effects of changes in living conditions is that they often tend to erode over time as a result of hedonic adaptation (e.g., Clark et al., 2008a; Oswald and Powdthavee, 2008). In particular, it has been found that people recover after sudden shocks in their income (Di Tella et al., 2010; Di Tella and MacCulloch, 2010), although often they only adapt partially (Van Landeghem, 2010; Mentesoglu and Vendrik, 2011). It is conceivable that the treated workers in our sample also become accustomed over time to the fact that they have reduced pension rights and accordingly adapt their assessment of their well-being. Although such a reduction of pension rights implies changes in expectations about future retirement conditions rather than instantaneous changes in living conditions, the psychological literature on happiness (Wilson et al., 2003) suggests that people adapt their happiness not only to changes in their living conditions after these have taken place, but also, in general, to any emotional event, and hence also to changes in their expectations about future conditions before these take place. The crucial factor that triggers such hedonic adaptation is that the changes have become definite and certain. A large part of the adaptation then tends to take place within two or three years (Clark et al., 2008a; Di Tella and MacCulloch, 2010). However, recent studies on relative concerns in happiness (Di Tella and McCulloch, 2010: Mentesoglu and Vendrik, 2011) strongly suggest that people do not adapt or adapt much less to changes in their relative position than they do to absolute alterations in their living conditions.

Because the main treatment effect that we find is entirely relative, we may expect that this effect has not much changed between 2008 and 2009. This can be tested by adding to equation (1) interaction terms of the treatment dummy and the birth date controls with the year of measurement. We would then expect a significant positive coefficient of the interaction term of the treatment dummy. In addition, we can investigate the persistence of the atmosphere effect and the social comparison effect for the treated by adding interaction terms of the fraction treated, and of the interaction between the treatment dummy and the fraction treated, with the year of measurement (as well as four corresponding regression discontinuity controls). The estimation results for this equation

\footnotetext{
${ }^{32}$ This column is a reproduction of Column 3 of Table 3.
} 
are shown in Column 3 of Table 4. It becomes clear that the changes in the treatment, atmosphere and social comparison effects from 2008 to 2009 are all statistically insignificant. Thus, there are no significant indications of hedonic adaptation to these effects over time, suggesting that the effects of the pension reform on job satisfaction are persistent.

Column 4 finally shows the estimation results for equation (2) extended with the corresponding interaction terms with year of measurement. These results confirm that the persistence of the social comparison effect on the treated workers implies persistence of the relative component of the main treatment effect (recall that $\widetilde{\beta}_{3}=-\beta_{3}$ in equation (2)), while the absolute component of the main treatment effect remains persistently insignificant. ${ }^{33}$

\subsection{Monetary and non-monetary components}

Since relative deprivation effects on job satisfaction have been found in the happiness literature to be both larger and more persistent over time than the absolute effects of worsening conditions, our finding that the main treatment effect is entirely relative partly explains why it is remarkably strong as well as stable between 2008 and 2009. However, why the effects of the pension reform are so much larger than the wage effect, as shown in Section 5.1, remains a puzzle since wage effects across individuals are mainly relative as well. This suggests that the effects of the reform may contain important non-monetary components in addition to the direct monetary effects due to the fall in the average expected replacement rate at age 62 from $70 \%$ to $64 \%$. For the treated workers such a nonmonetary effect could originate from feelings of being treated differently - and in this case unfairly from colleagues slightly older and born in $1949 .^{34}$

We test for the existence of non-monetary effects of the pension reform by adding as control variables to equation (2) the logarithms of the expected replacement rate at age $62\left(\ln r_{i t}\right)$, the average expected replacement rate at 62 of those born in 1949 and 1950 in the organization and income tertile of the respondent $\left(\ln \bar{r}_{i t}\right)$, and the individual replacement rate relative to the average replacement rate interacted with the treatment status of the employee $\left(T_{i}\left(\ln r_{i t}-\ln \bar{r}_{i t}\right)\right)$. This yields

\footnotetext{
${ }^{33}$ It is possible, however, that the initial effect of the reform on treated respondents in 2006 may have had both an absolute and a relative component, but that the respondents quickly became accustomed to the absolute component (as found for absolute income by Mentesoglu and Vendrik, 2011). Since we measure the main treatment effect two and three years after the reform, it could well be that the adaptation process of the absolute component had already taken place.

${ }^{34}$ Such a non-monetary effect would not arise from the rise in the average expected retirement age by three months of those born in 1950 since that represents an endogenous, behavioral, and assumedly utility-raising response to alleviate the negative effects of the lower replacement rate.
} 


$$
\begin{aligned}
J S_{i t}= & \alpha+\widetilde{\beta}_{1} T_{i}+\beta_{2} \bar{T}_{i t}+\widetilde{\beta}_{3} T_{i}\left(T_{i}-\bar{T}_{i t}\right)+\widetilde{\beta}_{4} \ln r_{i t}+\beta_{5} \ln \bar{r}_{i t}+\widetilde{\beta}_{6} T_{i}\left(\ln r_{i t}-\ln \bar{r}_{i t}\right)+\gamma_{1} B_{i}+\gamma_{2} B_{i} T_{i}+ \\
& +\gamma_{3} B_{i} \bar{T}_{i t}+\gamma_{4} B_{i} T_{i} \bar{T}_{i t}+\gamma_{5} B_{i}\left(\ln r_{i t}-\ln \bar{r}_{i t}\right)+\gamma_{6} B_{i} T_{i}\left(\ln r_{i t}-\ln \bar{r}_{i t}\right)+\boldsymbol{\delta}^{\prime} \mathbf{X}_{i t}+u_{i}+e_{i t} .
\end{aligned}
$$

In this equation the terms $\widetilde{\beta}_{4} \ln r_{i t}, \beta_{5} \ln \bar{r}_{i t}$, and $\widetilde{\beta}_{6} T_{i}\left(\ln r_{i t}-\ln \bar{r}_{i t}\right)$ control for the monetary components of the absolute treatment effect $\widetilde{\beta}_{1} T_{i}$, the atmosphere effect $\beta_{5} \bar{T}_{i t}$, and the relative treatment effect $\widetilde{\beta}_{3} T_{i}\left(T_{i}-\bar{T}_{i t}\right)$, respectively. The former terms should capture the direct monetary effects ${ }^{35}$, while the latter terms then represent the remaining non-monetary effects. ${ }^{36}$

The resulting coefficient estimates are shown in Column 1 of Table 5. As expected, the absolute effect of the individual replacement rate is small and statistically insignificant. The effect of the average replacement rate is small and statistically insignificant as well, indicating that there is no monetary component of the atmosphere effect. On the other hand, the coefficient of the individual replacement rate relative to the average replacement for the treated workers (0.812) is large and (weakly) statistically significant. Thus, the relative treatment effect has a strong monetary component, which indicates that treated workers feel frustrated by the relatively higher replacement rate of their untreated colleagues. Moreover, it follows that the overall monetary treatment effect on job satisfaction due to the fall in the expected replacement rate at age 62 seems entirely relative.

Table 5 also shows that the estimated coefficients of the fraction treated and relative treatment that are significant in Column 2 of Table 4 remain (weakly) significant and have only somewhat decreased in magnitude, while the absolute component of the treatment effect remains insignificant. This strongly suggests that the atmosphere and relative treatment effects on job satisfaction have indeed a strong non-monetary component and that relative concerns also play a dominant role in the non-monetary component of the treatment effect. Interpreting the non-monetary treatment effect as originating from feelings of being treated in an unfair manner compared to people slightly older and

\footnotetext{
${ }^{35}$ The coefficients of the individual and average replacement rates also pick up the effects of cross-sectional variation in replacement rates between different individuals when adaptation has worked out. In our case, it is likely that adaptation to the pension reform has likely worked out as well at the times of the survey (see the end of the previous section). Therefore, there is no clear reason why the former cross-sectional effects should bias the coefficients for the monetary effects of the pension reform. On the other hand, the coefficient of the individual replacement rate may be biased due to a spurious correlation via personality characteristics or reverse causality. Therefore, we have also estimated equation (3) controlling for Mundlak terms for the replacement rates (and the other control variables). Furthermore, measurement error in the individual replacement rate does not seem important as job satisfaction can be assumed to be affected by the subjective expectation about the individual replacement rate at age 62 as expressed in the questionnaire rather than by the true value of this replacement rate.

${ }^{36}$ In theory, the non-monetary treatment effect may also pick up the effect of the increase in pension contribution payments which was part of the pension reform (see Section 2). However, this increase was small and may barely have been noticed by those affected by the reform.
} 
born in 1949, we can even consider it as a social-comparison effect by its very nature. Columns 2-4 of Table 5 further show that our results are robust to the inclusion of Mundlak terms for the individual replacement rate, the average replacement rate, and all time-variant control variables.

We can also approximately assess the relative sizes of the non-monetary and monetary components of the effects of the pension reform. Appendix A2 shows that, for the estimates in Column (4) of Table 5, the total non-monetary effect of the pension reform on the job satisfaction of the treated workers constitutes, on average, a remarkably large $93.9 \%$ (with standard error $5.4 \%$ ) of the total treatment effect on job satisfaction. This implies a monetary component of only $6.1 \%$ of the total treatment effect (which is even insignificantly different from zero percent). As suggested above, the very strong non-monetary effect may be attributed to feelings of being treated unfairly among the men born in 1950. Both this non-monetary effect and the monetary effect of a lower expected replacement rate at age 62 on the job satisfaction of those born in 1950 can be considered as being fully relative. The untreated workers experience a non-monetary atmosphere effect on their job satisfaction which represents practically $100 \%$ (99.4\%) of the total net atmosphere effect on job satisfaction.

\section{Robustness analyses: heterogeneous effects}

\subsection{Team work and part-timers}

The degree to which workers socially compare themselves with colleagues in the same income tertile is likely to depend on the degree to which employees within an organization work together and have contact with each other. One can conjecture that employees in organizations that stimulate teamwork and apply fixed work hours are more likely to have contact with colleagues who are in the same age range and income tertile than those in organizations in which team work and fixed work hours are less prevalent. To test this hypothesis, we make use of answers to an employer survey that was sent to all public sector employers in 2011 (response rate was 46\%). The aim of the survey was to provide an overview of the HR-policies in the different subsectors of the public sector. It contains three important questions on the degree to which employers stimulate teamwork, whether most employees work in teams within organizations, and whether employers allow older workers to work part-time. ${ }^{37}$ We were able to match the responses to these questions on subsector level to our dataset.

\footnotetext{
${ }^{37}$ Respondents of the employer survey were mostly directors, general managers, HR-managers and HR officials. Respondents had to indicate on a five point Likert scale to which degree their organization stimulates employees to work in teams ( 1 means 'never' and 5 means 'always'). Furthermore, respondents had to indicate on a five point Likert scale how well the statements that most employees work in teams, and that older workers are allowed to work part-time apply to their organization (1 means 'does not apply at all' and 5 means 'applies perfectly').
} 
Table 6 shows separate regressions for workers in sectors in which employers strongly agree with the statements on stimulating team work, team work participation, and that older workers are allowed to work part-time (sector score above the median), and for workers in sectors in which employers disagree with these statements (sector score at or below the median). Column 1 of Table 6 shows that the main treatment, atmosphere and social comparison effects are highly statistically significant for employees in sectors in which team work is stimulated, while Column 2 shows that there is a significant main treatment effect for those in sectors in which team work is not stimulated, but no significant atmosphere and social comparison effects. This finding corroborates our expectations that the degree to which workers will socially compare themselves with colleagues in the same income tertile depends on the degree to which employees within an organization work together. Although the differences in effects are insignificant, Column 3-6 further suggest that the main treatment, atmosphere and social comparison effects are greater for employees who are more likely to work in teams and are not allowed to work part-time.

\subsection{The role of information}

Although a campaign was launched by the public sector's pension fund in the second half of 2005 to explain the implications of the new pension system for the pension rights of each individual, it remains conceivable that worker responses will depend on the capability of the treated workers to properly assess the consequences of the new pension system for their own pension rights, and the extent to which they are interested in their future pension income. We can assume that the job satisfaction of treated workers who have a good overview on the retrenchments of their pension rights and who have looked for information on their pension income is especially affected. Table 7 shows the results of separate regression analyses for workers who do have a good or bad overview (selfassessed) of their own pension, and for those who have looked intensively at their pension in the past year, and for those who did not. ${ }^{38}$ The results confirm our hypothesis in the sense that the main treatment, atmosphere and social comparison effects are more significant for workers who indicate that they are better capable to assess their pension rights, and who are more interested in their pension. $^{39}$

\footnotetext{
${ }^{38}$ Workers were asked to indicate whether they have a good overview of their pension rights (yes / no), and were asked to indicate on a scale from 0 (not looked at all) to 10 (looked very intensive) how intensively they have looked at their pension in the past year. We identify workers who answered 6 or more (median) as those who looked intensively, and workers who have a score below the median as those who did not look intensively.

${ }^{39}$ An exception is the more significant atmosphere effect for those who have not intensively looked at their pension.
} 


\subsection{Alternative sources of pension income}

One would further expect workers with alternative sources of pension income to be less affected by the policy reform since the pension they build at the public sector's pension fund comprises a smaller share of their total pension benefits. One of the major alternative private sources of pension income in the Netherlands on which information is available in our dataset is the surplus value that individuals have on their houses. Similarly, one would expect that the treatment effect on the well-being of the men in our sample varies with the expected pension income of their partners. The financial impact of the reform is greater for workers whose partner will not contribute to the household income after retirement. ${ }^{40}$ This may reinforce feelings of being treated unfairly.

Table 8 shows the results of separate analyses for men who have a below or above-median surplus value on their house, and for men whose partners do not have an own pension income versus men whose partner have an own pension income. We find that the estimation results are in line with our expectations. The job satisfaction of workers who have a below-median surplus value on their house are more significantly affected by the reform than those with a surplus value above the median. The social comparison and atmosphere effects are statistically significant for the first group, while there is no significant effect for the latter group. We find similar effects in the analyses for the men whose partners do not have an own pension income versus those whose partner have an own pension income.

\subsection{Window changes}

Although the previous analyses control for birth date, we should further examine the robustness of our results by conducting additional regressions on subsamples for a smaller age window around the treatment threshold. It is conceivable that the degree of social comparisons varies with the number of months workers were born before or after the threshold. More specifically, we expect that the introduction of a smaller age window will increase the likelihood that workers in the treatment and control groups compare themselves with each other. Moreover, individuals who just missed the old generous pension system by a few days or months may perceive the shock in their pension rights due to the arbitrary treatment threshold as particularly unfair. The results are presented in Table 9, which

\footnotetext{
${ }^{40} \mathrm{~A}$ recent and growing body of literature emphasizes the incidence of joint retirement among dual-career families and the increasing importance of spillover effects between the financial incentives of men and their spouses. Among others, Blau (1997, 1998), Baker (2002), and Coile (2004), find strong financial spillovers that affect individual retirement behavior.
} 
shows regressions on samples of workers born twelve, nine, and six months around the treatment threshold. $^{41}$

Table 9 shows a robust pattern in the size of the coefficients across the different age windows. For job satisfaction, the coefficient of the treatment dummy tends to increase when we select workers born closer to the treatment threshold. ${ }^{42}$ Furthermore, the atmosphere and social comparison effects seem to increase when we exclude those who were born further away from the treatment threshold. Although the differences in the coefficients between the windows are not significant, these results seem to buttress our previous findings by suggesting that especially treated workers who were born within nine months after the treatment threshold contaminate the atmosphere within their organization, and due to social comparison suffer less in their job (abstracting from the higher negative atmosphere effect) when they have more colleagues who were born just after the threshold, and hence suffer from the treatment as well.

\section{Conclusion}

This study used an exogenous shock in pension rights of Dutch public-sector workers to determine the extent to which a drop in the generosity of the pension system affects the well-being of workers nearing retirement. Prior to 2006, public sector workers in the Netherlands could retire at age 62 years and three months with a replacement rate of $70 \%$ of their average yearly earnings since 2002 . As of 2006, those born before January 1, 1950, can continue to retire under the old rules, but for those born on or after January 1, 1950, the replacement rate has been lowered to $64 \%$. These younger workers need to work an additional one year and one month to obtain the $70 \%$ replacement rate enjoyed by their counterparts who may be just a few days, weeks, or months older. We matched panel survey data that contain various indicators of well-being with administrative data of the public sector's pension fund, and estimated the individual well-being scores of male workers born in 1949 or 1950 two and three years after the shock in the pension system.

\footnotetext{
${ }^{41}$ It is not possible to introduce a smaller window around the treatment threshold, since the number of treated workers with whom workers can compare themselves becomes too small.

${ }^{42}$ In combination with the pattern of job satisfaction as a function of birth date in Figure A2, this may suggest a relief effect for those born just before the threshold date (October - December 1949), but the differences in the patterns are not significant. We checked that particularly those who just qualified (i.e., those born in October - December 1949) have a higher satisfaction level by performing analyses on those born in 1949 which include a dummy for whether one is born in the last three months of 1949 (results available on request). We find that the coefficient of this dummy is small and insignificant in our estimations for job satisfaction. Hence there is no convincing evidence for a relief effect.
} 
The results provide strong evidence that the shock in the pension system has a substantial and persistent effect on job satisfaction. The drop in job satisfaction is strongly affected by social comparisons with colleagues. Treated workers suffer less from the reform when the treatment group is larger in their organization. We also found that workers compared their own replacement rate with the average replacement of comparable colleagues in their organization, but the major part of the social comparison effect is non-monetary. Additionally, our estimates indicate a negative external effect of the percentage of treated employees on the job satisfaction of the workers in the organization, which is interpreted as an atmosphere effect. As expected, the social comparison effect is more significant for workers who work in sectors in which teamwork and full-time work hours are more prevalent, and for those who are better informed about their pension rights. Moreover, the social comparison effect is less significant for workers who have alternative sources of pension income or a partner who have a pension income of their own. To our knowledge, this is the first study to document these strong and persistent social comparison effects on individual well-being of altered expectations about future pension income caused by an exogenous shock in a retirement system.

The main advantage of this study is that, unlike previous studies that investigated the relevance of social comparisons for job satisfaction, we exploited unique data on a natural experiment that enabled us to use reference groups exogenously generated by the experiment. The limited age difference between the treatment and control groups in our sample and the simple and transparent birth year criterion determining entitlement to the old or new pension rights ensured that the reference group does not have significantly different characteristics. Furthermore, the experimental character of our study allowed us to shed more light on a causal relation between an exogenous change in retirement expectations and job satisfaction.

This study focused on public-sector employees for whom the pension change was more profound than for employees in the private sector of the economy. One can question whether the focus on the public sector restricts the generalizability of our results. Although caution is necessary when generalizing the results, our findings have great relevance for public policy. It should first be noted that the public sector in most European countries is the largest national employer (Pilichowski and Turkisch, 2008). Moreover, most industrialized countries are currently revising their pension systems to extend working life to cope with population aging. These reforms are not restricted to national retirement plans but do also apply to the retirement schemes of public sector workers (see Palacios and Whitehouse, 2006, for an overview of recent reforms of public sector pension plans in European countries). Since, the main objective of social policy is to promote the well-being of the population as a whole, policy makers should consider the negative side effects of the revisions in their pension systems and try to avoid social comparisons. Moreover, recent studies by Jones et al. (2008) and Clark 
et al. (2009) show that well-being is an important determinant of workplace performance and individual productivity. Therefore, it is important that the negative social comparison effects on job satisfaction found in this study are taken into account when modeling the effects of a decrease in the generosity of pensions on productive labor supply.

\section{Acknowledgements}

We gratefully acknowledge ABP for making the administrative data available. We acknowledge the comments and suggestions of Eric Bonsang, Lex Borghans, Frank Cörvers, Thomas Dohmen, Andries De Grip, Daniel Hamermesh, Ben Kriechel, Bert van Landeghem, Olivier Marie, Jan Rouwendal, Jan Sauermann, and the participants of the ROA Applied Economics seminar, the ESPE 2010 conference in Essen, the EALE/SOLE 2010 conference in London, the EEA 2010 conference in Glasgow, and the Netspar 2011 conference in Amsterdam.

\section{References}

Baker, M., 2002. The retirement behavior of married couples: Evidence from the spouse's allowance, Journal of Human Resources 37, 1-34.

Bender, K.A., 2004. The well-being of retirees: Evidence using subjective data. Center for Retirement Research Working Paper 2004-24, Boston College.

Blanchflower, D.G., Oswald, A.J., 2008. Is well-being U-shaped over the life cycle? Social Science and Medicine 66, 1733-1749.

Blau, D.M., 1997. Social security and the labor supply of older married couples. Journal of Labor Economics 4, 373-418.

Blau, D.M., 1998. Labor force dynamics of older married couples. Journal of Labor Economics 16, 595-629.

Börsch-Supan, A., 2000. Incentive effects of social security on labor force participation: Evidence in Germany and across Europe. Journal of Public Economics 78, 25-49.

Börsch-Supan, A., Jürges H., 2006. Early retirement, social security and well-being in Germany. NBER Working Paper 12303.

Bossé, R., Aldwin, C.M., Levenson, M.R., Ekerdt, D.J., 1987. Mental health differences among retirees and workers: Findings from the normative aging study. Psychology and Aging 2, $383-389$. 
Campbell, A., Converse, P.E., Rodgers, W.L., 1976. The Quality of American Life: Perception, Evaluation, and Satisfaction. New York: Sage.

Card, D., Mas, A., Moretti, E., Saez, E., 2010. Inequality at work: The effect of peer salaries on job satisfaction. NBER Working Paper 16396.

Carter, S., McBride, M., 2009, Experienced utility versus decision utility: Putting the "s" in satisfaction. Working Paper, Department of Economics, University of California, Irvine.

Charles, K., 2004. Is retirement depressing?: Labor force inactivity and psychological well-being in later life. Research in Labor Economics; 23, S.W. Polacheck, ed.

Clark, A.E., 2003. Unemployment as a social norm: Psychological evidence from panel data. Journal of Labor Economics 21, 323-351.

Clark, A.E., Diener, E., Georgellis, Y., Lucas, R.E., 2008a. Lags and leads in life satisfaction: A test of the baseline hypothesis. Economic Journal 118, F222-F243.

Clark, A.E., Frijters P., Shields M., 2008b. Relative income, happiness and utility: An explanation for the Easterlin paradox and other puzzles. Journal of Economic Literature 46, 95-144.

Clark, A.E., Knabe, A., and Rätzel, S., 2010, Boon or bane? Others' unemployment, well-being and job insecurity. Labour Economics 17, 52-61.

Clark, A.E., Masclet, D., Villeval, M.C., 2009. Effort and comparison income. Industrial and Labor Relations Review 63, 407-470.

Clark, A.E., Oswald, A.J., 1994. Unhappiness and unemployment. Economic Journal 104, 648-659.

Clark, A.E., Oswald, A.J., 1996. Satisfaction and comparison income. Journal of Public Economics 61, 359-381.

Clark, A.E., Senik, C., 2010. Who compares to whom? The autonomy of income comparisons in Europe. Economic Journal 120, 573-594.

Coile, C., 2004. Retirement incentives and couples' retirement decisions. Topics in Economic Analysis and Policy 4.

Coile, C., Gruber, J., 2007. Future social security entitlements and the retirement decision. Review of Economics and Statistics 89, 234-246.

Coile, C., Levine, P., 2007. Labor market shocks and retirement: Do government programs matter? Journal of Public Economics 91, 1902-1919.

Dave, D., Rashad, I., Spasojevic, J., 2006. The effects of retirement on physical and mental health outcomes. NBER Working Paper 12123.

De Grip, A., Lindeboom, M. ,Montizaan, R., 2012, Shattered Dreams: The Effect of Changing the Pension System Late in the Game, The Economic Journal 122: 1-25.

Dillman, D., 1978. Mail and Telephone Surveys: The Total Design Method. New York: Wiley. 
Di Tella, R., Haisken De-New, J. and MacCulloch, R. (2010), "Happiness Adaptation to Income and to Status in an Individual Panel”, Journal of Economic Behavior and Organization, 76: 834852.

Di Tella, R., and MacCulloch, R. (2010), "Happiness Adaptation to Income Beyond Basic Needs", in E. Diener, J. Helliwell and D. Kahneman (eds.), International Differences in Well-Being, Oxford University Press, New York.

Dreyer, P.H., 1989. Post-retirement life satisfaction. In S. Spacapan and S. Oscamp, eds., The Social Psychology of Aging. Newbury Park, CA: Sage Publications, pp. 109-133.

Duesenberry, J.S., 1949. Income, Saving and the Theory of Consumer Behavior. Cambridge, MA.

Easterlin, R.A., 1974. Does economic growth improve the human lot? Some empirical evidence. In: David, P.A., Reder M.W. (Eds.), Nations and households in economic growth: Essays in honor of Moses Abramowitz. Academic Press, New York and London, 89-125.

Easterlin, R.A.,1995. Will raising the incomes of all increase the happiness of all? Journal of Economic Behavior and Organization 27, 35-47.

Euwals, R., Van Vuuren D.J., Wolthoff, R.P., 2006. Early retirement behaviour in the Netherlands: Evidence from a policy reform. IZA Working Paper 1992.

Falba, T., Gallo, W., Sindelar, J., 2008. Work expectations, realizations and depression in older workers. NBER Working Paper 14435.

Fehr, E., Schmidt, K.M., 1999. A theory of fairness, competition, and cooperation. Quarterly Journal of Economics 114, 817-868.

Ferrer-i-Carbonell, 2005. Income and well-being: An empirical analysis of the comparison income effect. Journal of Public Economics 89. 997-1019.

Ferrer-i-Carbonell, A., Frijters, P., 2004. How important is methodology for the estimates of the determinants of happiness? Economic Journal 114, 641-659.

Frey, B.S., Stutzer, A., 2002a. Happiness and Economics: How the Economy and Institutions Affect Well-Being. Oxford: Princeton University Press.

Frey, B.S., Stutzer, A., 2002b. What can economists learn from happiness research? Journal of Economic Literature 40, 402-435.

Gardner, J., Oswald, A.J., 2006. Do divorcing couples become happier by breaking up? Journal of the Royal Statistical Society Series A 169, 319-336.

Gardner, J., Oswald A.J., 2007. Money and mental wellbeing: A longitudinal study of medium-sized lottery wins. Journal of Health Economics 26, 49-60.

Gruber, J., Wise, D.A., 2004. Social Security Programs and Retirement around the World: MicroEstimation. NBER Books. 
Harrison, G., List, J., 2004. Field experiments. Journal of Economic Literature 42, 1013-1059.

Jones, M.K., Jones, R.J., Latreille, P.L., Sloane, P.J., 2008. Training, job satisfaction and workplace performance in Britain: Evidence from WERS 2004. IZA Discussion Paper 3677.

Kapteyn, A., 1998. Social security and labor force participation in the Netherlands. American Economic Review 88, 164-167.

Kim, J., Moen, P., 2002. Retirement transitions, gender, and psychological well-being: A life-course approach. Journal of Gerontology: Psychological Sciences 57B, P212-P222.

Krueger, A.B., Schkade, D.A., 2008. The reliability of subjective well-being measures. Journal of Public Economics 92, 1933-1845.

Layard, R., Mayraz, G., Nickell, S., 2009. Does relative income matter? Are the critics right? CEP Discussion Paper, No. 918.

Lucas, R., 2005. Time does not heal all wounds - A longitudinal study of reaction and adaptation to divorce. Psychological Science 16, 945-950.

Luechinger, S., 2009. Valuing air quality using the life satisfaction approach. Economic Journal 119, $482-515$.

Luttmer, E., 2005. Neighbors as negatives: Relative earnings and well-being. Quarterly Journal of Economics 120, 963-1002.

McBride, M., 2001. Relative-income effects on subjective well-being in the cross-section. Journal of Economic Behavior and Organization 45(3), 251-278.

Mentesoglu, G., Vendrik, M., 2011. Adaptation, anticipation and social interaction in happiness. Working Paper, Department of Economics, Maastricht University.

Montizaan, R., De Grip, A., Cörvers, F., Dohmen, T., 2012, Demotivating Workers: Retrenchment of Pension Rights and Negative Reciprocity, Working paper

Mundlak, Y., 1978. On the pooling of time series and cross-section data. Econometrica, 46, 69-85.

Nuttman-Shwartz, O., 2004. Like a high wave: Adjustment to retirement, Gerontologist 44, 229-236.

Oswald, A.J., Powdthavee, N., 2008. Does happiness adapt? A longitudinal study of disability with implications for economists and judges. Journal of Public Economics 92, 1061-1077.

Palacios, R., Whitehouse, E., 2006. Civil-service pension schemes around the world. SP Discussion Paper, No. 0602.

Pilichowski, E., Turkisch, E., 2008. Employment in government in the perspective of the production costs of goods and services in the public sector. OECD Working Papers on Public Governance, No. 8.

Prenda, K.M., Lachman, M.E., 2001. Planning for the future: A life management strategy for increasing control and life satisfaction in adulthood. Psychology and Aging 16, 206-216. 
Statistics Netherlands, 2009. Statline. Labour Force Survey.

Thompson G.B., 1973. Work leisure roles: An investigation of morale among employed and retirement men, Journal of Gerontology 28, 339-344.

TNS Nipo, 2006. ABP marktmonitor 12-meting e5351, Amsterdam.

Van Landeghem, B. (2010), "Adaptation of Subjective Well-being to Income", in: B. Van Landeghem, Essays on Subjective Well-Being, PhD Thesis, Katholieke Universiteit Leuven, Faculty of Economics and Business Administration, Ch. 5, pp. 119-159

Van der Klaauw, W., 2002. Estimating the effect of financial aid offers on college enrollment: A regression-discontinuity approach. International Economic Review 43, 1249-1287.

Vendrik, M.C.M., Woltjer, G., 2007. Happiness and loss aversion: When social participation dominates comparison. Journal of Public Economics 91, 1423-1448.

Williamson, O. 1973. Markets and hierarchies: Some elementary considerations. American Economic Review 63, 316-325.

Wilson, T.D., Gilbert, D.T., Centerbar, D.B., 2003. Making sense: The causes of emotional evanescence. In I. Brocas and J.D. Carillo, eds., The Psychology of Economic Decisions: Rationality and Well-Being. Oxford University Press, Ch. 11, pp. 209-234.

Winkelmann, L., Winkelmann, R., 1998. Why are the unemployed so unhappy? Evidence from panel data. Economica 65, 1-15.

Zárraga, C., Bonache, J., 2005. The impact of team atmosphere on knowledge outcomes in selfmanaged teams. Organization Studies 26, 661-681. 


\section{Figures}

Fig. 1 Job satisfaction

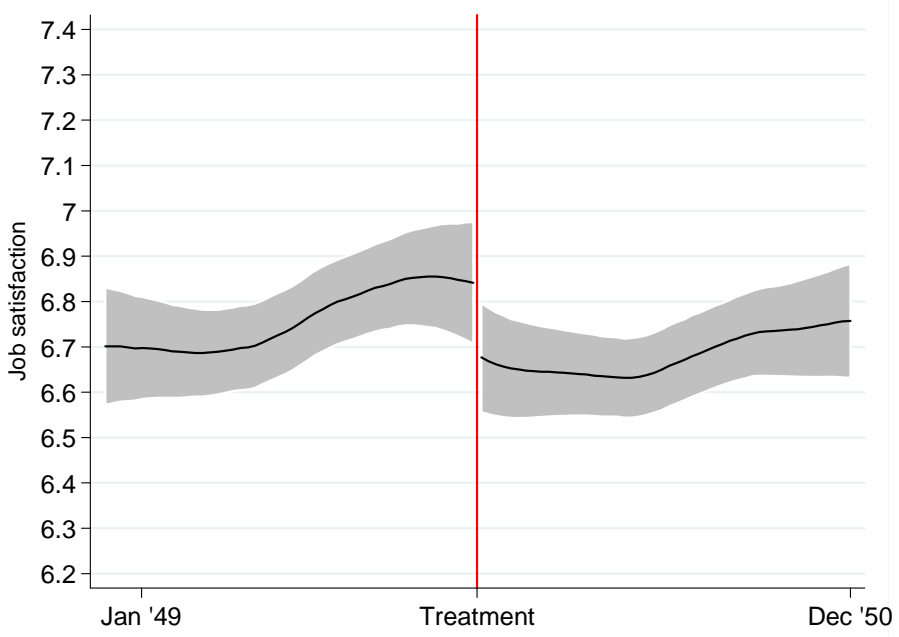

This figure presents a local polynomial smooth of job satisfaction on birth date, using a Epanechnikov kernel function. The bandwidth for the kernel function is obtained using the ROT method of bandwidth selection. The ROT bandwidth is the plug-in estimator of the asymptotically optimal constant bandwidth which minimizes the conditional weighted mean integrated squared error.

\section{Fig. 2. Expected retirement benefits at age 62}

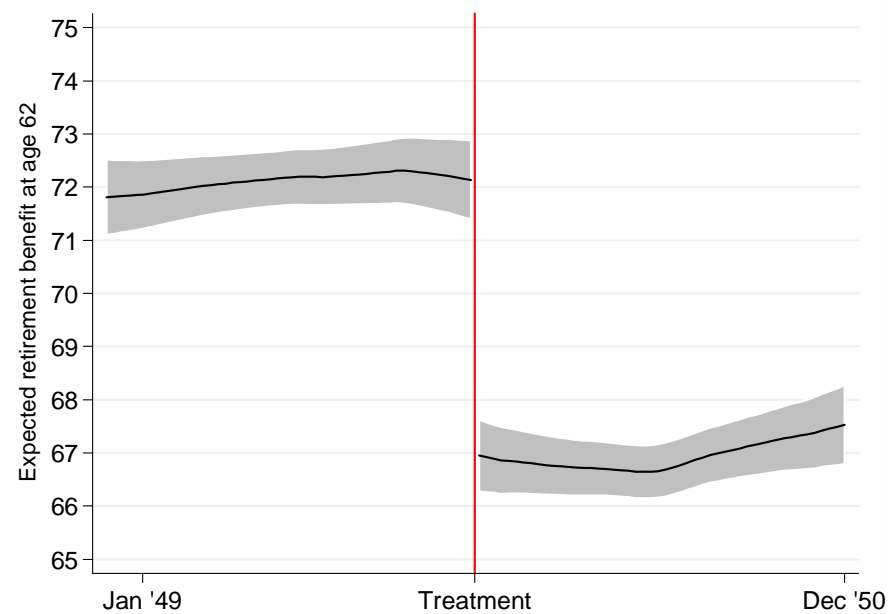

This figure presents a local polynomial smooth of the expected retirement benefit at age 62 in percentage of average wage income on birth date, using a Epanechnikov kernel function. The bandwidth for the kernel function is obtained using the ROT method of bandwidth selection. The information used is based on the following survey question asked in 2009: 'Suppose you would retire at the age of 62 . How large would your pension benefit be (in percentage of your net wage income)?' The vertical line in the figure marks the threshold dividing the control and treatment groups. 
Table 1. Descriptive statistics

\begin{tabular}{|c|c|c|c|c|c|c|c|c|c|c|}
\hline & (1) & (2) & (3) & (4) & (5) & (6) & (7) & (8) & (9) & $(\mathbf{1 0})$ \\
\hline & \multicolumn{5}{|c|}{2008} & \multicolumn{5}{|c|}{2009} \\
\hline & Mean & St. Dev. & Born in 1950 & Born in 1949 & T-stat. & Mean & St. Dev. & Born in 1950 & Born in 1949 & T-stat. \\
\hline \multicolumn{11}{|l|}{ Satisfactions } \\
\hline Job satisfaction & 6.72 & 1.83 & 6.69 & 6.75 & 1.30 & 7.02 & 1.66 & 6.96 & 7.09 & 2.86 \\
\hline Life satisfaction & 7.66 & 1.26 & 7.61 & 7.71 & 2.81 & 7.82 & 1.18 & 7.77 & 7.87 & 3.47 \\
\hline Satisfaction with wage & 6.45 & 1.90 & 6.45 & 6.45 & 0.02 & 6.88 & 1.69 & 6.84 & 6.93 & 1.87 \\
\hline Satisfaction with hours worked & 6.81 & 1.88 & 6.73 & 6.89 & 3.26 & 6.90 & 1.80 & 6,83 & 6.99 & 3.47 \\
\hline Satisfaction with leisure & NA & NA & NA & NA & NA & 7.12 & 1.81 & 7.02 & 7.24 & 4.70 \\
\hline Satiafaction with household income & NA & NA & NA & NA & NA & 7.31 & 1.58 & 7.29 & 7.34 & 1.33 \\
\hline Satisfaction with health & NA & NA & NA & NA & NA & 7.21 & 1.83 & 7.19 & 7.25 & 1.37 \\
\hline \multicolumn{11}{|l|}{ Retirement expectations } \\
\hline Expected replacement rate at age 62 & 69.42 & 11.75 & 67.00 & 72.10 & 16.07 & 65.72 & 12.49 & 63.38 & 68.40 & 15.96 \\
\hline Expected replacement rate at age 63 & NA & NA & NA & NA & NA & 73.19 & 12.90 & 69.92 & 76.92 & 22.00 \\
\hline Expected replacement rate at age 65 & NA & NA & NA & NA & NA & 81.42 & 13.69 & 81.10 & 81.80 & 2.02 \\
\hline Expected retirement age & 62,00 & 2.57 & 62.11 & 61.88 & 3.17 & 63.27 & 1.700 & 63.45 & 63.06 & 9.21 \\
\hline \multicolumn{11}{|l|}{ Job characteristics and wealth } \\
\hline Yearly wage (in logs) & 10.83 & 0.28 & 10.83 & 10.84 & 0.94 & 10.83 & 0.29 & 10.83 & 10.84 & 1.91 \\
\hline Years contributed to the pension fund & 31.12 & 6.35 & 30.45 & 31.86 & 8.26 & 32.98 & 6.59 & 31.41 & 33.64 & 7.59 \\
\hline Investments in life course savings plan & NA & NA & NA & NA & NA & 0.10 & 0.30 & 0.14 & 0.05 & 13.12 \\
\hline Contractual working hours & 0.99 & 0.05 & 0.99 & 0.99 & 0.06 & 0.99 & 0.06 & 0.99 & 0.99 & 0.58 \\
\hline \multicolumn{11}{|l|}{ Other personal characteristics } \\
\hline Married & 0.92 & 0.28 & 0.91 & 0.92 & 1.73 & 0.91 & 0.28 & 0.90 & 0.92 & 2.96 \\
\hline Lower secundary education & 0.11 & 0.31 & 0.12 & 0.10 & 1.59 & 0.11 & 0.32 & 0.11 & 0.11 & 0.02 \\
\hline Higher secundary education & 0.04 & 0.19 & 0.04 & 0.04 & 0.17 & 0.04 & 0.20 & 0.04 & 0.04 & 1.73 \\
\hline Vocational education & 0.14 & 0.34 & 0.13 & 0.14 & 0.59 & 0.15 & 0.36 & 0.15 & 0.15 & 0.33 \\
\hline Higher education & 0.61 & 0.49 & 0.61 & 0.61 & 0.76 & 0.63 & 0.48 & 0.63 & 0.64 & 1.29 \\
\hline Number of doctor visits & 2.12 & 2.53 & 2.13 & 2.12 & 0.02 & 2.24 & 2.75 & 2.20 & 2.28 & 1.23 \\
\hline
\end{tabular}


Table 2 Descriptive Statistics of organizations

Mean St. Dev

Number of treated (by organization and income bracket) $\quad 32.86 \quad 65.06$

Number of untreated (by organization and income bracket) $\quad 30.64 \quad 62.97$

$\begin{array}{lll}\text { Fraction treated (by organization and income bracket) } & 0.52 & 0.23\end{array}$

$\begin{array}{lll}\text { Average replacement rate (by organization and income bracket) } & 68.33 & 8.09\end{array}$ 
Table 3 Reference-based effects: the effects of the fraction of treated workers within organizations and income brackets

\begin{tabular}{|c|c|c|c|}
\hline VARIABLES & $(1)$ & $(2)$ & (3) \\
\hline \multicolumn{4}{|l|}{ Main variables } \\
\hline Treatment (dummy own treatment) & $\begin{array}{c}-0.221 * * * \\
(0.071)\end{array}$ & $\begin{array}{c}-0.223 * * * \\
(0.072)\end{array}$ & $\begin{array}{c}-0.583 * * * \\
(0.205)\end{array}$ \\
\hline Fraction treated (by organization and income bracket) & & & $\begin{array}{c}-0.584 * * \\
(0.253)\end{array}$ \\
\hline Treatment $\mathrm{x}$ fraction treated & & & $\begin{array}{l}0.769 * * \\
(0.362)\end{array}$ \\
\hline \multicolumn{4}{|l|}{ Birth date controls } \\
\hline Birth date & $\begin{array}{c}0.110 \\
(0.095)\end{array}$ & $\begin{array}{c}0.035 \\
(0.099)\end{array}$ & $\begin{array}{c}0.134 \\
(0.196)\end{array}$ \\
\hline Birth date $\mathrm{x}$ treatment & $\begin{array}{c}0.038 \\
(0.129)\end{array}$ & $\begin{array}{c}0.144 \\
(0.133)\end{array}$ & $\begin{array}{c}0.008 \\
(0.367)\end{array}$ \\
\hline Birth date $\mathrm{x}$ fraction treated & & & $\begin{array}{l}-0.235 \\
(0.439)\end{array}$ \\
\hline Birth date $\mathrm{x}$ treatment $\mathrm{x}$ fraction treated & & & $\begin{array}{c}0.294 \\
(0.652)\end{array}$ \\
\hline \multicolumn{4}{|l|}{ Other control variables } \\
\hline Yearly wage (ln) & & $\begin{array}{c}0.565^{* * *} * \\
(0.098)\end{array}$ & $\begin{array}{c}0.548 * * * \\
(0.099)\end{array}$ \\
\hline Marital status & & $\begin{array}{c}0.198 * * * \\
(0.071)\end{array}$ & $\begin{array}{c}0.200 * * * \\
(0.071)\end{array}$ \\
\hline Years contributed to the pension fund & & $\begin{array}{c}-0.008^{* * *} \\
(0.003)\end{array}$ & $\begin{array}{c}-0.008^{* * *} \\
(0.003)\end{array}$ \\
\hline Contractual working hours & & $\begin{array}{c}1.321^{* * *} \\
(0.384)\end{array}$ & $\begin{array}{c}1.307 * * * \\
(0.384)\end{array}$ \\
\hline Number of doctor visits & & $\begin{array}{c}-0.106^{* * *} \\
(0.007)\end{array}$ & $\begin{array}{c}-0.106^{* * *} * \\
(0.007)\end{array}$ \\
\hline Year of measurement & $\begin{array}{c}0.245 * * * \\
(0.023)\end{array}$ & $\begin{array}{c}0.253 * * * \\
(0.024)\end{array}$ & $\begin{array}{c}0.253^{* * * *} \\
(0.024)\end{array}$ \\
\hline Constant & $\begin{array}{c}6.862 * * * \\
(0.057)\end{array}$ & $\begin{array}{l}-0.097 \\
(1.149)\end{array}$ & $\begin{array}{c}0.369 \\
(1.178)\end{array}$ \\
\hline Observations & 11,415 & 9,978 & 9,978 \\
\hline Number of individuals & 7,770 & 6,993 & 6,993 \\
\hline
\end{tabular}

$* * *=\mathrm{p}<0.01, * *=\mathrm{p}<0.05, *=\mathrm{p}<0.10$. Standard errors are in parentheses. The estimations in Columns 2-3 include educational level and sub-sector fixed effects as additional control variables. Birth date is expressed in days, normalized to 0 at December 31, 1949, and divided by 365. 
Table 4 Reference-based effects: relative treatment effect and adaptation

\begin{tabular}{|c|c|c|c|c|}
\hline VARIABLES & $(1)$ & $(2)$ & (3) & (4) \\
\hline \multicolumn{5}{|l|}{ Main variables } \\
\hline Treatment (dummy own treatment) & $\begin{array}{c}-0.583 * * * \\
(0.205)\end{array}$ & $\begin{array}{c}0.186 \\
(0.193)\end{array}$ & $\begin{array}{c}-0.687 * * * \\
(0.254)\end{array}$ & $\begin{array}{c}0.158 \\
(0.244)\end{array}$ \\
\hline Fraction treated (by organization and income bracket) & $\begin{array}{c}-0.584^{* *} \\
(0.253)\end{array}$ & $\begin{array}{c}-0.584 * * \\
(0.253)\end{array}$ & $\begin{array}{l}-0.414 \\
(0.329)\end{array}$ & $\begin{array}{c}-0.414 \\
(0.329)\end{array}$ \\
\hline Treatment $\mathrm{x}$ fraction treated & $\begin{array}{c}0.769^{* *} \\
(0.362)\end{array}$ & & $\begin{array}{l}0.845^{*} \\
(0.457)\end{array}$ & \\
\hline Treatment $\mathrm{x}$ (treatment - fraction treated) & & $\begin{array}{c}-0.769 * * \\
(0.362)\end{array}$ & & $\begin{array}{c}-0.845^{*} \\
(0.457)\end{array}$ \\
\hline \multicolumn{5}{|l|}{ Birth date controls } \\
\hline Birth date & $\begin{array}{c}0.134 \\
(0.196)\end{array}$ & $\begin{array}{c}0.134 \\
(0.196)\end{array}$ & $\begin{array}{c}0.112 \\
(0.251)\end{array}$ & $\begin{array}{c}0.112 \\
(0.251)\end{array}$ \\
\hline Birth date $\mathrm{x}$ treatment & $\begin{array}{c}0.008 \\
(0.367)\end{array}$ & $\begin{array}{c}0.008 \\
(0.367)\end{array}$ & $\begin{array}{c}0.356 \\
(0.461)\end{array}$ & $\begin{array}{c}0.356 \\
(0.461)\end{array}$ \\
\hline Birth date $\mathrm{x}$ fraction treated & $\begin{array}{l}-0.235 \\
(0.439)\end{array}$ & $\begin{array}{l}-0.235 \\
(0.439)\end{array}$ & $\begin{array}{c}0.015 \\
(0.561)\end{array}$ & $\begin{array}{c}0.015 \\
(0.561)\end{array}$ \\
\hline Birth date $\mathrm{x}$ treatment $\mathrm{x}$ fraction treated & $\begin{array}{c}0.294 \\
(0.652)\end{array}$ & $\begin{array}{c}0.294 \\
(0.652)\end{array}$ & $\begin{array}{l}-0.470 \\
(0.819)\end{array}$ & $\begin{array}{c}-0.470 \\
(0.819)\end{array}$ \\
\hline \multicolumn{5}{|l|}{ Adaptation } \\
\hline Year of measurement & $\begin{array}{c}0.253 * * * \\
(0.024)\end{array}$ & $\begin{array}{c}0.253 * * * \\
(0.024)\end{array}$ & $\begin{array}{c}0.318 * * \\
(0.155)\end{array}$ & $\begin{array}{c}0.318^{* *} \\
(0.155)\end{array}$ \\
\hline Year of measurement $\mathrm{x}$ treatment & & & $\begin{array}{c}0.208 \\
(0.254)\end{array}$ & $\begin{array}{c}0.031 \\
(0.258)\end{array}$ \\
\hline Year of measurement $\mathrm{x}$ fraction treated & & & $\begin{array}{l}-0.288 \\
(0.348)\end{array}$ & $\begin{array}{c}-0.288 \\
(0.348)\end{array}$ \\
\hline Year of measurement $\mathrm{x}$ treatment $\mathrm{x}$ fraction treated & & & $\begin{array}{c}-0.177 \\
(0.470)\end{array}$ & \\
\hline Year of measurement $\mathrm{x}$ treatment $\mathrm{x}$ (treatment - fraction treated) & & & & $\begin{array}{c}0.177 \\
(0.470)\end{array}$ \\
\hline Year of measurement $\mathrm{x}$ birth date & & & $\begin{array}{c}0.019 \\
(0.249)\end{array}$ & $\begin{array}{c}0.019 \\
(0.249)\end{array}$ \\
\hline Year of measurement $\mathrm{x}$ birth date $\mathrm{x}$ treatment & & & $\begin{array}{l}-0.625 \\
(0.462)\end{array}$ & $\begin{array}{l}-0.625 \\
(0.462)\end{array}$ \\
\hline Year of measurement $\mathrm{x}$ birth date $\mathrm{x}$ fraction treated & & & $\begin{array}{l}-0.406 \\
(0.555)\end{array}$ & $\begin{array}{l}-0.406 \\
(0.555)\end{array}$ \\
\hline Year of measurement $\mathrm{x}$ birth date $\mathrm{x}$ treatment $\mathrm{x}$ fraction treated & & & $\begin{array}{c}1.369 \\
(0.836)\end{array}$ & $\begin{array}{c}1.369 \\
(0.836)\end{array}$ \\
\hline \multicolumn{5}{|l|}{ Other control variables } \\
\hline Yearly wage (ln) & $\begin{array}{c}0.548^{* * *} \\
(0.099)\end{array}$ & $\begin{array}{c}0.548^{* * *} \\
(0.099)\end{array}$ & $\begin{array}{c}0.544 * * * \\
(0.099)\end{array}$ & $\begin{array}{c}0.544 * * * \\
(0.099)\end{array}$ \\
\hline Marital Status & $\begin{array}{c}0.200^{* * *} \\
(0.071)\end{array}$ & $\begin{array}{c}0.200 * * * \\
(0.071)\end{array}$ & $\begin{array}{c}0.200 * * * \\
(0.071)\end{array}$ & $\begin{array}{c}0.200^{* * *} * \\
(0.071)\end{array}$ \\
\hline Years contributed to the pension fund & $\begin{array}{c}-0.008^{* * * *} \\
(0.003)\end{array}$ & $\begin{array}{c}-0.008^{* * *} * \\
(0.003)\end{array}$ & $\begin{array}{c}-0.008^{* * *} \\
(0.003)\end{array}$ & $\begin{array}{c}-0.008^{* * *} \\
(0.003)\end{array}$ \\
\hline Contractual working hours & $\begin{array}{c}1.307 * * * \\
(0.384)\end{array}$ & $\begin{array}{c}1.307 * * * \\
(0.384)\end{array}$ & $\begin{array}{c}1.308 * * * \\
(0.384)\end{array}$ & $\begin{array}{c}1.308 * * * \\
(0.384)\end{array}$ \\
\hline Number of doctor visits & $\begin{array}{c}-0.106^{* * * *} \\
(0.007)\end{array}$ & $\begin{array}{c}-0.106 * * * \\
(0.007)\end{array}$ & $\begin{array}{c}-0.106^{* * *} \\
(0.007)\end{array}$ & $\begin{array}{c}-0.106 * * * \\
(0.007)\end{array}$ \\
\hline Constant & $\begin{array}{c}0.369 \\
(1.178)\end{array}$ & $\begin{array}{c}0.369 \\
(1.178)\end{array}$ & $\begin{array}{c}0.361 \\
(1.176)\end{array}$ & $\begin{array}{c}0.361 \\
(1.176)\end{array}$ \\
\hline Observations & 9,978 & 9,978 & 9,978 & 9,978 \\
\hline Number of individuals & 6,993 & 6,993 & 6,993 & 6,993 \\
\hline
\end{tabular}

$* * *=p<0.01, * *=p<0.05, *=p<0.10$. Standard errors in parentheses. All estimations include educational levels and sub-sector fixed effects as additional control variables. Birth date is expressed in days, normalized to 0 at December 31 , 1949, and divided by 365 . 
Table 5 Reference-based effects: the effects of the fraction of treated workers and of comparison of replacement rates within organizations and income brackets

\begin{tabular}{|c|c|c|c|c|}
\hline VARIABLES & $(1)$ & (2) & (3) & (4) \\
\hline \multicolumn{5}{|l|}{ Main variables } \\
\hline Treatment (dummy own treatment) & $\begin{array}{c}0.179 \\
(0.199)\end{array}$ & $\begin{array}{c}0.177 \\
(0.198)\end{array}$ & $\begin{array}{c}0.181 \\
(0.199)\end{array}$ & $\begin{array}{c}0.166 \\
(0.198)\end{array}$ \\
\hline Fraction treated (by organization and income bracket) & $\begin{array}{c}-0.588^{* *} \\
(0.258)\end{array}$ & $\begin{array}{c}-0.589^{* *} \\
(0.258)\end{array}$ & $\begin{array}{c}-0.592 * * \\
(0.258)\end{array}$ & $\begin{array}{c}-0.552^{* *} \\
(0.258)\end{array}$ \\
\hline Treatment $\mathrm{x}$ (treatment - fraction treated) & $\begin{array}{c}-0.679^{*} \\
(0.366)\end{array}$ & $\begin{array}{c}-0.679^{*} \\
(0.366)\end{array}$ & $\begin{array}{c}-0.689^{*} \\
(0.366)\end{array}$ & $\begin{array}{c}-0.645^{*} \\
(0.365)\end{array}$ \\
\hline Replacement rate $(\ln )$ & $\begin{array}{l}-0.144 \\
(0.306)\end{array}$ & $\begin{array}{l}-0.102 \\
(0.324)\end{array}$ & $\begin{array}{l}-0.091 \\
(0.324)\end{array}$ & $\begin{array}{l}-0.100 \\
(0.322)\end{array}$ \\
\hline \multirow[t]{2}{*}{$\begin{array}{l}\text { Average replacement rate (by organization and income } \\
\text { bracket, } \ln \text { ) }\end{array}$} & 0.055 & 0.054 & 0.025 & 0.023 \\
\hline & $(0.332)$ & $(0.332)$ & $(0.332)$ & $(0.329)$ \\
\hline Treatment $x$ (replacement rate - average replacement rate) & $\begin{array}{l}0.812^{*} \\
(0.479)\end{array}$ & $\begin{array}{l}0.809^{*} \\
(0.478)\end{array}$ & $\begin{array}{l}0.807^{*} \\
(0.478)\end{array}$ & $\begin{array}{l}0.775^{*} \\
(0.467)\end{array}$ \\
\hline \multicolumn{5}{|l|}{ Birth date controls } \\
\hline Birth date & $\begin{array}{c}0.127 \\
(0.200)\end{array}$ & $\begin{array}{c}0.127 \\
(0.200)\end{array}$ & $\begin{array}{c}0.127 \\
(0.200)\end{array}$ & $\begin{array}{c}0.088 \\
(0.200)\end{array}$ \\
\hline Birth date $\mathrm{x}$ Treatment dummy & $\begin{array}{l}-0.081 \\
(0.375)\end{array}$ & $\begin{array}{l}-0.082 \\
(0.375)\end{array}$ & $\begin{array}{l}-0.077 \\
(0.376)\end{array}$ & $\begin{array}{l}-0.047 \\
(0.378)\end{array}$ \\
\hline Birthdate $\mathrm{x}$ fraction treated & $\begin{array}{l}-0.192 \\
(0.447)\end{array}$ & $\begin{array}{l}-0.191 \\
(0.447)\end{array}$ & $\begin{array}{l}-0.192 \\
(0.448)\end{array}$ & $\begin{array}{l}-0.125 \\
(0.448)\end{array}$ \\
\hline Birth date $\mathrm{x}$ treatment dummy $\mathrm{x}$ fraction treated & $\begin{array}{c}0.357 \\
(0.669)\end{array}$ & $\begin{array}{c}0.359 \\
(0.669)\end{array}$ & $\begin{array}{c}0.353 \\
(0.669)\end{array}$ & $\begin{array}{c}0.297 \\
(0.673)\end{array}$ \\
\hline Birth date $\mathrm{x}$ (replacement rate - average replacement rate) & $\begin{array}{l}-0.834 \\
(0.569)\end{array}$ & $\begin{array}{l}-0.826 \\
(0.568)\end{array}$ & $\begin{array}{l}-0.822 \\
(0.568)\end{array}$ & $\begin{array}{l}-0.786 \\
(0.563)\end{array}$ \\
\hline $\begin{array}{l}\text { Birth date } \mathrm{x} \text { treatment dummy } \mathrm{x} \text { (replacement rate - average } \\
\text { replacement rate) }\end{array}$ & $\begin{array}{l}0.276 \\
(0.777)\end{array}$ & $\begin{array}{l}0.265 \\
(0.776)\end{array}$ & $\begin{array}{l}0.258 \\
(0.777)\end{array}$ & 0.280 \\
\hline \multicolumn{5}{|l|}{ Other control variables } \\
\hline Yearly wage $(\ln )$ & $\begin{array}{c}0.574 * * * \\
(0.101)\end{array}$ & $\begin{array}{c}0.572 * * * \\
(0.101)\end{array}$ & $\begin{array}{c}0.574 * * * \\
(0.101)\end{array}$ & $\begin{array}{c}-0.308 \\
(15.462)\end{array}$ \\
\hline Marital Status & $\begin{array}{c}0.191 * * * \\
(0.070)\end{array}$ & $\begin{array}{c}0.190 * * * \\
(0.070)\end{array}$ & $\begin{array}{c}0.191 * * * \\
(0.070)\end{array}$ & $\begin{array}{c}0.357 \\
(0.296)\end{array}$ \\
\hline Years contributed to the pension fund & $\begin{array}{c}-0.008 * * \\
(0.003)\end{array}$ & $\begin{array}{c}-0.008 * * \\
(0.003)\end{array}$ & $\begin{array}{c}-0.008 * * \\
(0.003)\end{array}$ & $\begin{array}{c}-0.035^{* *} \\
(0.014)\end{array}$ \\
\hline Contractual working hours & $\begin{array}{c}1.334 * * * \\
(0.396)\end{array}$ & $\begin{array}{c}1.332 * * * \\
(0.396)\end{array}$ & $\begin{array}{c}1.334 * * * \\
(0.396)\end{array}$ & $\begin{array}{c}0.572 \\
(3.694)\end{array}$ \\
\hline Number of doctor visits & $\begin{array}{c}-0.107 * * * \\
(0.007)\end{array}$ & $\begin{array}{c}-0.107 * * * \\
(0.007)\end{array}$ & $\begin{array}{c}-0.107 * * * \\
(0.007)\end{array}$ & $\begin{array}{c}-0.054 * * * \\
(0.013)\end{array}$ \\
\hline Year of measurement & $\begin{array}{c}0.245^{* * *} \\
(0.025)\end{array}$ & $\begin{array}{c}0.246^{* * *} \\
(0.025)\end{array}$ & $\begin{array}{c}0.244 * * * \\
(0.025)\end{array}$ & $\begin{array}{c}0.264 * * * \\
(0.029)\end{array}$ \\
\hline Mundlak individual replacement rate & & $\begin{array}{l}-0.069 \\
(0.167)\end{array}$ & $\begin{array}{l}-0.082 \\
(0.169)\end{array}$ & $\begin{array}{c}-0.084 \\
(0.170)\end{array}$ \\
\hline Mundlak average replacement rate & & & $\begin{array}{c}0.047 \\
(0.059)\end{array}$ & $\begin{array}{c}0.020 \\
(0.059)\end{array}$ \\
\hline Constant & $\begin{array}{c}0.558 \\
(1.445)\end{array}$ & $\begin{array}{c}0.688 \\
(1.479)\end{array}$ & $\begin{array}{c}0.608 \\
(1.482)\end{array}$ & $\begin{array}{c}0.837 \\
(1.534)\end{array}$ \\
\hline Observations & 9,693 & 9,693 & 9,693 & 9,693 \\
\hline Number of individuals & 6,814 & 6,814 & 6,814 & 6,814 \\
\hline
\end{tabular}


Table 6 Reference-based effects: Working in teams and part-time work

\begin{tabular}{|c|c|c|c|c|c|c|}
\hline VARIABLES & $\begin{array}{c}\text { (1) } \\
\text { Employer } \\
\text { stimulates } \\
\text { employees to } \\
\text { work in } \\
\text { teams }\end{array}$ & $\begin{array}{c}\text { (2) } \\
\text { Employer } \\
\text { does not } \\
\text { stimulate } \\
\text { employees to } \\
\text { work in } \\
\text { teams } \\
\end{array}$ & $\begin{array}{c}\text { (3) } \\
\text { Most } \\
\text { employees } \\
\text { work in } \\
\text { teams }\end{array}$ & $\begin{array}{c}\text { (4) } \\
\text { Most } \\
\text { employees do } \\
\text { not work in } \\
\text { teams }\end{array}$ & $\begin{array}{c}\text { (5) } \\
\text { Older } \\
\text { workers are } \\
\text { generally not } \\
\text { allowed to } \\
\text { work part- } \\
\text { time } \\
\end{array}$ & $\begin{array}{c}\text { (6) } \\
\text { Older } \\
\text { workers are } \\
\text { generally } \\
\text { allowed to } \\
\text { work part- } \\
\text { time } \\
\end{array}$ \\
\hline \multicolumn{7}{|l|}{ Main variables } \\
\hline Treatment (dummy own treatment) & $\begin{array}{c}-0.632 * * \\
(0.279)\end{array}$ & $\begin{array}{l}-0.573^{*} \\
(0.308)\end{array}$ & $\begin{array}{c}-0.627 * * * \\
(0.239)\end{array}$ & $\begin{array}{l}-0.546 \\
(0.441)\end{array}$ & $\begin{array}{c}-0.670 * * \\
(0.263)\end{array}$ & $\begin{array}{l}-0.415 \\
(0.312)\end{array}$ \\
\hline Fraction treated (by organization and income bracket) & $\begin{array}{c}-0.908 * * * \\
(0.338)\end{array}$ & $\begin{array}{l}-0.297 \\
(0.382)\end{array}$ & $\begin{array}{c}-0.555^{*} \\
(0.302)\end{array}$ & $\begin{array}{l}-0.785 \\
(0.550)\end{array}$ & $\begin{array}{c}-0.850 * * \\
(0.345)\end{array}$ & $\begin{array}{l}-0.250 \\
(0.364)\end{array}$ \\
\hline Treatment $\mathrm{x}$ fraction treated & $\begin{array}{c}0.967 * * \\
(0.486)\end{array}$ & $\begin{array}{c}0.663 \\
(0.551)\end{array}$ & $\begin{array}{c}0.839 * * \\
(0.421)\end{array}$ & $\begin{array}{c}0.702 \\
(0.794)\end{array}$ & $\begin{array}{c}0.956^{* *} \\
(0.477)\end{array}$ & $\begin{array}{c}0.445 \\
(0.539)\end{array}$ \\
\hline \multicolumn{7}{|l|}{ Birth date controls } \\
\hline Birth date & $\begin{array}{c}0.375 \\
(0.277)\end{array}$ & $\begin{array}{l}-0.077 \\
(0.279)\end{array}$ & $\begin{array}{c}0.116 \\
(0.214)\end{array}$ & $\begin{array}{c}0.150 \\
(0.492)\end{array}$ & $\begin{array}{l}0.507^{*} \\
(0.278)\end{array}$ & $\begin{array}{l}-0.238 \\
(0.273)\end{array}$ \\
\hline Birth date $\mathrm{x}$ treatment & $\begin{array}{l}-0.135 \\
(0.482)\end{array}$ & $\begin{array}{c}0.091 \\
(0.547)\end{array}$ & $\begin{array}{c}0.066 \\
(0.414)\end{array}$ & $\begin{array}{c}0.051 \\
(0.880)\end{array}$ & $\begin{array}{l}-0.329 \\
(0.497)\end{array}$ & $\begin{array}{c}0.199 \\
(0.549)\end{array}$ \\
\hline Birth date $\mathrm{x}$ fraction treated & $\begin{array}{l}-0.959 \\
(0.599)\end{array}$ & $\begin{array}{c}0.407 \\
(0.615)\end{array}$ & $\begin{array}{l}-0.306 \\
(0.521)\end{array}$ & $\begin{array}{l}-0.166 \\
(0.989)\end{array}$ & $\begin{array}{l}-0.817 \\
(0.619)\end{array}$ & $\begin{array}{c}0.366 \\
(0.611)\end{array}$ \\
\hline Birth date $\mathrm{x}$ treatment $\mathrm{x}$ fraction treated & $\begin{array}{c}0.861 \\
(0.845)\end{array}$ & $\begin{array}{l}-0.136 \\
(0.963)\end{array}$ & $\begin{array}{c}0.350 \\
(0.726)\end{array}$ & $\begin{array}{c}0.076 \\
(1.599)\end{array}$ & $\begin{array}{c}0.570 \\
(0.835)\end{array}$ & $\begin{array}{c}0.209 \\
(1.007)\end{array}$ \\
\hline Observations & 4,899 & 5,083 & 5,425 & 4,553 & 4,220 & 5,758 \\
\hline Number of individuals & 3,459 & 3,534 & 3,787 & 3,206 & 2,999 & 3,999 \\
\hline
\end{tabular}

$* * *=p<0.01, * *=p<0.05, *=p<0.10$. Standard errors are in parentheses. All estimations control for the same set of control variables as in Column 3 of Table 3 . 
Table 7 Reference-based effects and the role of information

\begin{tabular}{|c|c|c|c|c|}
\hline VARIABLES & $\begin{array}{c}(1) \\
\text { Good } \\
\text { overview of } \\
\text { own pension }\end{array}$ & $\begin{array}{c}\text { (2) } \\
\text { Bad overview } \\
\text { of own } \\
\text { pension }\end{array}$ & $\begin{array}{c}\text { (3) } \\
\text { Looked at } \\
\text { own pension } \\
\text { intensively in } \\
\text { the past year }\end{array}$ & $\begin{array}{c}\text { (4) } \\
\text { Did not look } \\
\text { at own } \\
\text { pension } \\
\text { intensively in } \\
\text { the past year }\end{array}$ \\
\hline \multicolumn{5}{|l|}{ Main variables } \\
\hline Treatment (dummy own treatment) & $\begin{array}{c}-0.555^{*} \\
(0.295)\end{array}$ & $\begin{array}{l}-0.387 \\
(0.476)\end{array}$ & $\begin{array}{c}-1.264 * * * \\
(0.366)\end{array}$ & $\begin{array}{l}-0.187 \\
(0.239)\end{array}$ \\
\hline Fraction treated (by organization and income bracket) & $\begin{array}{c}-0.845^{* *} \\
(0.356)\end{array}$ & $\begin{array}{c}0.446 \\
(0.625)\end{array}$ & $\begin{array}{l}-0.460 \\
(0.438)\end{array}$ & $\begin{array}{c}-0.771 * * \\
(0.311)\end{array}$ \\
\hline Treatment $\mathrm{x}$ fraction treated & $\begin{array}{l}1.154 * * \\
(0.513)\end{array}$ & $\begin{array}{l}-0.474 \\
(0.860)\end{array}$ & $\begin{array}{l}1.353 * * \\
(0.630)\end{array}$ & $\begin{array}{c}0.551 \\
(0.442)\end{array}$ \\
\hline \multicolumn{5}{|l|}{ Birth date controls } \\
\hline Birth date & $\begin{array}{c}0.052 \\
(0.269)\end{array}$ & $\begin{array}{c}0.242 \\
(0.486)\end{array}$ & $\begin{array}{c}0.226 \\
(0.343)\end{array}$ & $\begin{array}{c}0.065 \\
(0.235)\end{array}$ \\
\hline Birth date $\mathrm{x}$ treatment & $\begin{array}{c}0.096 \\
(0.527)\end{array}$ & $\begin{array}{l}-0.080 \\
(0.846)\end{array}$ & $\begin{array}{c}0.348 \\
(0.640)\end{array}$ & $\begin{array}{l}-0.217 \\
(0.422)\end{array}$ \\
\hline Birth date $\mathrm{x}$ fraction treated & $\begin{array}{c}-0.492 \\
(0.603)\end{array}$ & $\begin{array}{c}0.703 \\
(1.030)\end{array}$ & $\begin{array}{c}0.075 \\
(0.751)\end{array}$ & $\begin{array}{l}-0.572 \\
(0.512)\end{array}$ \\
\hline Birth date $\mathrm{x}$ treatment $\mathrm{x}$ fraction treated & $\begin{array}{c}0.241 \\
(0.916)\end{array}$ & $\begin{array}{l}-0.482 \\
(1.504)\end{array}$ & $\begin{array}{l}-0.516 \\
(1.100)\end{array}$ & $\begin{array}{c}0.911 \\
(0.763)\end{array}$ \\
\hline Observations & 5,297 & 2,511 & 3,936 & 6,046 \\
\hline Number of individuals & 3,255 & 1,576 & 2,988 & 4,005 \\
\hline
\end{tabular}

$* * *=\mathrm{p}<0.01, * *=\mathrm{p}<0.05, *=\mathrm{p}<0.10$. Standard errors are in parentheses. All estimations control for the same set of control variables as in Column 3 of Table 3. 
Table 8 Reference-based effects, the estimated surplus value of respondents' houses and income of the partner

\begin{tabular}{|c|c|c|c|c|}
\hline VARIABLES & $\begin{array}{c}\text { (1) } \\
\text { Surplus value } \\
\text { below median }\end{array}$ & $\begin{array}{c}(2) \\
\text { Surplus value } \\
\text { above median }\end{array}$ & $\begin{array}{c}(3) \\
\text { Partner has no } \\
\text { own pension } \\
\text { income }\end{array}$ & $\begin{array}{c}\text { (4) } \\
\text { Partner has } \\
\text { own pension } \\
\text { income } \\
\end{array}$ \\
\hline \multicolumn{5}{|l|}{ Main variables } \\
\hline Treatment (dummy own treatment) & $\begin{array}{c}-0.797 * * \\
(0.372)\end{array}$ & $\begin{array}{c}-0.475 \\
(0.351)\end{array}$ & $\begin{array}{c}-0.744 * * \\
(0.373)\end{array}$ & $\begin{array}{l}-0.233 \\
(0.342)\end{array}$ \\
\hline Fraction treated (by organization and income bracket) & $\begin{array}{c}-1.026^{* *} \\
(0.466)\end{array}$ & $\begin{array}{c}-0.850^{* *} \\
(0.382)\end{array}$ & $\begin{array}{c}-0.608 \\
(0.418)\end{array}$ & $\begin{array}{l}-0.459 \\
(0.409)\end{array}$ \\
\hline Treatment $\mathrm{x}$ fraction treated & $\begin{array}{l}1.300^{*} \\
(0.676)\end{array}$ & $\begin{array}{c}0.649 \\
(0.590)\end{array}$ & $\begin{array}{l}1.182^{*} \\
(0.676)\end{array}$ & $\begin{array}{c}0.437 \\
(0.600)\end{array}$ \\
\hline \multicolumn{5}{|l|}{ Birth date controls } \\
\hline Birth date & $\begin{array}{c}0.151 \\
(0.311)\end{array}$ & $\begin{array}{c}0.332 \\
(0.312)\end{array}$ & $\begin{array}{l}-0.007 \\
(0.334)\end{array}$ & $\begin{array}{c}0.172 \\
(0.334)\end{array}$ \\
\hline Birth date $\mathrm{x}$ treatment & $\begin{array}{c}0.212 \\
(0.611)\end{array}$ & $\begin{array}{l}-0.903 \\
(0.637)\end{array}$ & $\begin{array}{c}0.227 \\
(0.695)\end{array}$ & $\begin{array}{l}-0.913 \\
(0.604)\end{array}$ \\
\hline Birth date $\mathrm{x}$ fraction treated & $\begin{array}{l}-0.597 \\
(0.736)\end{array}$ & $\begin{array}{l}-0.751 \\
(0.704)\end{array}$ & $\begin{array}{c}0.009 \\
(0.712)\end{array}$ & $\begin{array}{l}-0.387 \\
(0.734)\end{array}$ \\
\hline Birth date $\mathrm{x}$ treatment $\mathrm{x}$ fraction treated & $\begin{array}{l}0.480 \\
0.151\end{array}$ & $\begin{array}{c}1.942^{*} \\
0.332\end{array}$ & $\begin{array}{l}-0.296 \\
(1.193)\end{array}$ & $\begin{array}{l}1.737 \\
(1.084)\end{array}$ \\
\hline Observations & 2,651 & 3,106 & 2,628 & 2,983 \\
\hline Number of individuals & 2,279 & 2,605 & 2,166 & 2,540 \\
\hline
\end{tabular}

$* * *=\mathrm{p}<0.01, * *=\mathrm{p}<0.05, *=\mathrm{p}<0.10$. Standard errors are in parentheses. All estimations control for the same set of control variables as in Column 3 of Table 3. 
Table 9 Reference-based effects and window changes

\begin{tabular}{lccc}
\hline VARIABLES & $\begin{array}{c}(1) \\
\text { Born within } \\
\text { twelve } \\
\text { months }\end{array}$ & $\begin{array}{c}(2) \\
\text { Born within } \\
\text { nine months }\end{array}$ & $\begin{array}{c}(3) \\
\text { Born within } \\
\text { six months }\end{array}$ \\
\hline Main variables & $-0.583^{* * *}$ & $-0.896^{* * *}$ & $-0.777^{* * *}$ \\
Treatment (dummy own treatment) & $(0.205)$ & $(0.235)$ & $(0.290)$ \\
Fraction treated (by organization and income bracket) & $-0.584^{* *}$ & $-0.789^{* * *}$ & $-0.650^{*}$ \\
& $(0.253)$ & $(0.293)$ & $(0.349)$ \\
Treatment x fraction treated & $0.769^{* *}$ & $1.314^{* * *}$ & $1.118^{* *}$ \\
& $(0.362)$ & $(0.420)$ & $(0.511)$ \\
Birth date controls & 0.134 & $0.567 *$ & -0.165 \\
Birth date & $(0.196)$ & $(0.337)$ & $(0.600)$ \\
Birth date x treatment & 0.008 & 0.207 & 0.672 \\
& $(0.367)$ & $(0.568)$ & $(1.069)$ \\
Birth date x fraction treated & -0.235 & -0.950 & 0.073 \\
& $(0.439)$ & $(0.721)$ & $(1.250)$ \\
Birth date x treatment $x$ fraction treated & 0.294 & -0.182 & -0.447 \\
& $(0.652)$ & $(1.030)$ & $(1.825)$ \\
Observations & 9,978 & 7,508 & 5,079 \\
Number of individuals & 6,993 & 5,255 & 3,542
\end{tabular}

$* * *=\mathrm{p}<0.01, * *=\mathrm{p}<0.05, *=\mathrm{p}<0.10$. Standard errors are in parentheses. All estimations control for the same set of control variables as in Column 3 of Table 3 . 


\section{Appendix A1: Robustness analyses}

Tabel A1 Alternative models and specifications (job satisfaction)

\begin{tabular}{lccc}
\hline VARIABLES & $\begin{array}{c}(1) \\
\text { OLS }\end{array}$ & $\begin{array}{c}(2) \\
\text { Random effect } \\
\text { models including } \\
\text { Mundlak terms }\end{array}$ & $\begin{array}{c}(3) \\
\text { Ordered probit }\end{array}$ \\
\hline Main variables & $-0.633 * * *$ & $-0.557^{* * *}$ & $-0.367^{* * *}$ \\
Treatment (dummy own treatment) & $(0.210)$ & $(0.204)$ & $-0.130)$ \\
Fraction treated (by organization and income & $-0.624 * *$ & $-0.549 * *$ & $-0.408^{* *}$ \\
bracket) & $(0.255)$ & $(0.252)$ & $(0.165)$ \\
& $0.872^{* *}$ & $0.733^{* *}$ & $0.532^{* *}$ \\
Treatment $x$ fraction treated & $(0.370)$ & $(0.361)$ & $(0.232)$ \\
Birth date controls & 0.122 & 0.098 & 0.048 \\
Birth date & $(0.197)$ & $(0.196)$ & $(0.132)$ \\
Birth date $x$ treatment & 0.082 & 0.038 & 0.007 \\
& $(0.382)$ & $(0.369)$ & $(0.236)$ \\
Birth date $x$ fraction treated & -0.225 & -0.172 & -0.102 \\
& $(0.447)$ & $(0.439)$ & $(0.292)$ \\
Birth date $x$ treatment $x$ fraction treated & 0.157 & 0.238 & 0.157 \\
& $(0.675)$ & $(0.656)$ & $(0.424)$ \\
Observations & 9,978 & 9,978 & 9,978 \\
Number of individuals & 6,993 & 6,993 & 6,993 \\
\hline$* *$ p $<0.01, * *=\mathrm{p}<0.05, *=\mathrm{p}<0.10$. Standard errors are in parentheses. All estimations control for the
\end{tabular}
same set of control variables as in Column 3 of Table 3. 
Tabel A2 Alternative income brackets (job satisfaction)

\begin{tabular}{lcc}
\hline VARIABLES & $\begin{array}{c}(\mathbf{1}) \\
\text { Income bracket } \\
\mathbf{1 0 \%}\end{array}$ & $\begin{array}{c}\mathbf{( 2 )} \\
\text { Income bracket } \\
\mathbf{2 0 \%}\end{array}$ \\
\hline Main variables & $-0.557^{* * *}$ & $-0.553^{* * *}$ \\
Treatment (dummy own treatment) & $(0.194)$ & $(0.212)$ \\
Fraction treated (by organization and income bracket) & $-0.490^{* *}$ & $-0.607^{* *}$ \\
Treatment $x$ fraction treated & $(0.238)$ & $(0.263)$ \\
Birth date controls & $0.709 * *$ & $0.720^{*}$ \\
Birth date & $(0.340)$ & $(0.377)$ \\
& & 0.151 \\
Birth date $x$ treatment & 0.122 & $(0.208)$ \\
Birth date $x$ fraction treated & $(0.181)$ & -0.102 \\
Birth date $x$ treatment $x$ fraction treated & 0.174 & $(0.378)$ \\
Observations & $(0.335)$ & -0.265 \\
Number of individuals & -0.219 & $(0.455)$ \\
\hline
\end{tabular}

$* * *=\mathrm{p}<0.01, * *=\mathrm{p}<0.05, *=\mathrm{p}<0.10$. Standard errors are in parentheses. All estimations control for the same set of control variables as in Column 3 of Table 3 . 
Table A3 Reference-based effects: Controlling for the size and age structure of organizations

\begin{tabular}{|c|c|c|}
\hline VARIABLES & $(1)$ & $(2)$ \\
\hline \multicolumn{3}{|l|}{ Main variables } \\
\hline Treatment (dummy own treatment) & $\begin{array}{c}-0.574 * * * \\
(0.205)\end{array}$ & $\begin{array}{c}-0.583 * * * \\
(0.204)\end{array}$ \\
\hline Fraction treated (by organization and income bracket) & $\begin{array}{c}-0.584 * * \\
(0.252)\end{array}$ & $\begin{array}{c}-0.592^{* *} \\
(0.252)\end{array}$ \\
\hline Treatment $\mathrm{x}$ fraction treated & $\begin{array}{c}0.753^{* *} \\
(0.363)\end{array}$ & $\begin{array}{c}0.766^{* *} \\
(0.362)\end{array}$ \\
\hline \multicolumn{3}{|l|}{ Birth date controls } \\
\hline Birth date & $\begin{array}{c}0.137 \\
(0.196)\end{array}$ & $\begin{array}{c}0.140 \\
(0.196)\end{array}$ \\
\hline Birth date $\mathrm{x}$ treatment & $\begin{array}{c}0.002 \\
(0.366)\end{array}$ & $\begin{array}{l}-0.002 \\
(0.367)\end{array}$ \\
\hline Birth date $\mathrm{x}$ fraction treated & $\begin{array}{l}-0.245 \\
(0.437)\end{array}$ & $\begin{array}{l}-0.243 \\
(0.438)\end{array}$ \\
\hline Birth date $\mathrm{x}$ treatment $\mathrm{x}$ fraction treated & $\begin{array}{c}0.310 \\
(0.650)\end{array}$ & $\begin{array}{c}0.308 \\
(0.652)\end{array}$ \\
\hline \multicolumn{3}{|l|}{ Organization characteristics } \\
\hline Organization size (divided by 1,000 ) & $\begin{array}{c}-0.004 * \\
(0.002)\end{array}$ & \\
\hline Size of the $1949 / 1950$ group as fraction of the total organization size & & $\begin{array}{l}-0.014 \\
(0.011)\end{array}$ \\
\hline Observations & 9,978 & 9,978 \\
\hline Number of individuals & 6,993 & 6,993 \\
\hline
\end{tabular}

$* * *=\mathrm{p}<0.01, * *=\mathrm{p}<0.05, *=\mathrm{p}<0.10$. Standard errors are in parentheses. All estimations control for the same set of control variables as in Column 3 of Table 3. 
Table A4 Placebo analyses: reference-based effects on life satisfaction and other domains of life satisfaction

\begin{tabular}{|c|c|c|c|c|c|c|}
\hline VARIABLES & $\begin{array}{c}(1) \\
\text { Life } \\
\text { satisfaction }\end{array}$ & $\begin{array}{c}\text { (2) } \\
\begin{array}{c}\text { Satisfaction with } \\
\text { health }\end{array}\end{array}$ & $\begin{array}{c}(3) \\
\text { Satisfaction with } \\
\text { hours worked }\end{array}$ & $\begin{array}{c}\text { (4) } \\
\text { Satisfaction } \\
\text { with leisure }\end{array}$ & $\begin{array}{c}(5) \\
\begin{array}{c}\text { Satisfaction with } \\
\text { household } \\
\text { income }\end{array}\end{array}$ & $\begin{array}{c}(6) \\
\text { Satisfaction with } \\
\text { wage }\end{array}$ \\
\hline \multicolumn{7}{|l|}{ Main variables } \\
\hline Treatment (dummy own treatment) & $\begin{array}{l}-0.077 \\
(0.156)\end{array}$ & $\begin{array}{c}-0.475 * * \\
(0.234)\end{array}$ & $\begin{array}{c}-0.636^{* * *} \\
(0.217)\end{array}$ & $\begin{array}{c}-0.574 * * \\
(0.285)\end{array}$ & $\begin{array}{c}-0.064 \\
(0.211)\end{array}$ & $\begin{array}{c}-0.142 \\
(0.208)\end{array}$ \\
\hline Fraction treated (by organization and income bracket) & $\begin{array}{l}-0.063 \\
(0.203)\end{array}$ & $\begin{array}{c}-0.623 * * \\
(0.304)\end{array}$ & $\begin{array}{c}-0.467^{*} \\
(0.281)\end{array}$ & $\begin{array}{l}-0.527 \\
(0.324)\end{array}$ & $\begin{array}{c}0.011 \\
(0.263)\end{array}$ & $\begin{array}{l}-0.190 \\
(0.267)\end{array}$ \\
\hline Treatment $\mathrm{x}$ fraction treated & $\begin{array}{l}-0.078 \\
(0.286)\end{array}$ & $\begin{array}{l}0.789^{*} \\
(0.430)\end{array}$ & $\begin{array}{c}0.958^{* *} \\
(0.390)\end{array}$ & $\begin{array}{c}0.947 * * \\
(0.481)\end{array}$ & $\begin{array}{c}0.113 \\
(0.382)\end{array}$ & $\begin{array}{c}0.194 \\
(0.366)\end{array}$ \\
\hline \multicolumn{7}{|l|}{ Birth date controls } \\
\hline Birth date & $\begin{array}{l}-0.112 \\
(0.153)\end{array}$ & $\begin{array}{c}0.125 \\
(0.229)\end{array}$ & $\begin{array}{c}0.321 \\
(0.231)\end{array}$ & $\begin{array}{l}-0.015 \\
(0.260)\end{array}$ & $\begin{array}{c}0.007 \\
(0.203)\end{array}$ & $\begin{array}{c}0.130 \\
(0.206)\end{array}$ \\
\hline Birth date $\mathrm{x}$ treatment & $\begin{array}{l}-0.085 \\
(0.262)\end{array}$ & $\begin{array}{l}-0.047 \\
(0.393)\end{array}$ & $\begin{array}{c}-0.153 \\
(0.387)\end{array}$ & $\begin{array}{c}0.005 \\
(0.505)\end{array}$ & $\begin{array}{l}-0.304 \\
(0.397)\end{array}$ & $\begin{array}{c}-0.493 \\
(0.373)\end{array}$ \\
\hline Birth date $\mathrm{x}$ fraction treated & $\begin{array}{c}0.393 \\
(0.336)\end{array}$ & $\begin{array}{l}-0.329 \\
(0.511)\end{array}$ & $\begin{array}{l}-0.594 \\
(0.481)\end{array}$ & $\begin{array}{l}-0.409 \\
(0.552)\end{array}$ & $\begin{array}{c}0.018 \\
(0.441)\end{array}$ & $\begin{array}{l}-0.170 \\
(0.445)\end{array}$ \\
\hline Birth date $\mathrm{x}$ treatment $\mathrm{x}$ fraction treated & $\begin{array}{l}-0.088 \\
(0.473)\end{array}$ & $\begin{array}{c}0.384 \\
(0.712)\end{array}$ & $\begin{array}{c}0.058 \\
(0.686)\end{array}$ & $\begin{array}{c}0.266 \\
(0.887)\end{array}$ & $\begin{array}{c}0.267 \\
(0.675)\end{array}$ & $\begin{array}{c}0.655 \\
(0.638)\end{array}$ \\
\hline Observations & 9,984 & 5,435 & 9,977 & 5,428 & 5,420 & 9,972 \\
\hline Number of individuals & 6,996 & & 6,993 & & & 6,994 \\
\hline
\end{tabular}

$* * *=p<0.01, * *=p<0.05, *=p<0.10$. Standard errors are in parentheses. All estimations control for the same set of control variables as in Column 3 of Table 3 . The satisfaction domains in Columns 2,4 , and 5 are only available in the 2009 survey wave. 


\section{Appendix A2}

Equation (3) implies that the total non-monetary effect of the pension reform on the job satisfaction of the treated workers is given by $\widetilde{\beta}_{1}+\beta_{2} \bar{T}_{i t}+\widetilde{\beta}_{3}\left(1-\bar{T}_{i t}\right)=\widetilde{\beta}_{1}+\widetilde{\beta}_{3}+\left(\beta_{2}-\widetilde{\beta}_{3}\right) \bar{T}_{i t}$. Taking the sample mean 0.522 of the fraction treated $\bar{T}_{i t}$ then implies an average non-monetary effect of $\widetilde{\beta}_{1}+\widetilde{\beta}_{3}+0.522\left(\beta_{2}-\widetilde{\beta}_{3}\right)$. For the estimates in Column (4) of Table 5 this amounts to a fall in job satisfaction of the treated workers of -0.431 .

The total monetary effect of the pension reform on the job satisfaction of the treated workers is given by $\widetilde{\beta}_{4} \Delta \ln r_{i t}+\beta_{5} \Delta \ln \bar{r}_{i t}+\widetilde{\beta}_{6}\left(\Delta \ln r_{i t}-\Delta \ln \bar{r}_{i t}\right)=\left(\widetilde{\beta}_{4}+\widetilde{\beta}_{6}\right) \Delta \ln r_{i t}+\left(\beta_{5}-\widetilde{\beta}_{6}\right) \Delta \ln \bar{r}_{i t}$, where $\Delta \ln r_{i t}$ $=\ln \left(r_{\text {it }}\right.$ after reform $)-\ln \left(r_{i t}\right.$ before reform $)=\ln r_{i t}-\ln \left(r_{i t}+6\right) \quad$ and $\quad \Delta \ln \bar{r}_{i t}=\ln \left(\bar{r}_{i t}\right.$ after reform $)$ $-\ln \left(\bar{r}_{i t}\right.$ before reform $)=\ln \bar{r}_{i t}-\ln \left(\bar{r}_{i t}+\bar{T}_{i t} 6\right)$. Calculating the sample means of $\ln r_{i t}, \ln \left(r_{i t}+6\right), \ln \bar{r}_{i t}$, and $\ln \left(\bar{r}_{i t}+\bar{T}_{i t} 6\right)$ then yields an average monetary effect on treated workers of $-0.1244\left(\widetilde{\beta}_{4}+\widetilde{\beta}_{6}\right)-0.0743\left(\beta_{5}-\widetilde{\beta}_{6}\right)$. For the estimates in Column (4) of Table 5 this amounts to a fall in job satisfaction of the treated workers of -0.028 .

The total non-monetary effect of the pension reform on the job satisfaction of the treated workers as a percentage of the total treatment effect on the job satisfaction of the treated workers is then given by

$\frac{\widetilde{\beta}_{1}+\widetilde{\beta}_{3}+0.522\left(\beta_{2}-\widetilde{\beta}_{3}\right)}{\widetilde{\beta}_{1}+\widetilde{\beta}_{3}+0.522\left(\beta_{2}-\widetilde{\beta}_{3}\right)-0.1244\left(\widetilde{\beta}_{4}+\widetilde{\beta}_{6}\right)-0.0743\left(\beta_{5}-\widetilde{\beta}_{6}\right)} 100=\frac{-0.431}{-0.431-0.028} 100=93.9 \%$

The standard error in this parameter function is $5.4 \%$. The total monetary effect of the pension reform on the job satisfaction of the treated workers is then $100-93.9=6.1 \%$ of the total treatment effect with the same standard error of 5.4\%. This implies that this percentage is insignificant.

The total non-monetary effect of the pension reform on the job satisfaction of the untreated workers is the atmosphere effect given by $\beta_{2} \bar{T}_{i t}$. On average, this effect equals $0.522 \beta_{2}=0.522 *-0.552=-0.288$ for the estimate in Column (4) of Table 5. The corresponding monetary effect is $\beta_{5} \Delta \ln \bar{r}_{i t}$, which, on average, equals the insignificant $-0.0743 \beta_{5}=-0.0743 * 0.023=-0.0017$. This implies that the non-monetary atmosphere effect represents $[-0.288 /(-0.288-0.0017)]^{*} 100=99.4 \%$ of the total atmosphere effect, which is insignificantly different from $100 \%$. 